\title{
CUSTODY DISPUTES IN THE PROVINCIAL COURT OF ALBERTA: A NEW JUDICIAL DISPUTE RESOLUTION MODEL
}

\author{
THE HONOURABLE HUGH F. LANDERKIN ${ }^{\circ}$
}

In Alberta there is no uniform process or guideline for the application of the best interests of the child standard in custody disputes. The author asserts that in the absence of such provisions, the Provincial Court is free to develop its own process. The process for the application of the best interests of the child standard should be flexible so that each case may be treated individually, but, at the same time, follow defined standards. The author suggests that the Court must define community standards so that litigants understand the criteria used in decision-making. For many people, if the process is open and understandable then they are more likely to feel that justice has been done even in the face of an adverse result. The author addresses these process-based concerns by offering a new threestage model for custody dispute resolution. In the first stage the author suggests that details of how the child is functioning in his or her home, neighbourhood, and school should be explicilly outlined in an affidavit. The affidavit should emphasize the community values and child-centred perspective to be used by the Court. In the second, judicial dispute resolution, the author envisages a mediation that incorporates mini-trial procedure with the judge acting as an active participant in a non-adversarial context. If this fails, the presiding judge must step aside in favour of an independent judge and a regular trial will commence.
En Alberta, il n'existe aucune procédure ou directive uniforme concernant l'application du principe de primauté des intérêts de l'enfant dans les litiges portant sur la garde. Cette lacune autorise l'auteur à conclure que la cour provinciale est donc libre d'élaborer sa propre procédure. Celle-ci devrait être suffisamment flexible pour que chaque cas puisse être traité individuellement, dans le respect des critères établis. L'auteur estime que la cour doit definir des normes communautaires qui permettront aux plaideurs de comprendre les critères motivant le processus décisionnel. Dans la majorité des cas, quand le processus est ouvert et transparent, les citoyens tendent à se sentir mieux servis par la justice - même quand la décision leur est défavorable. L'auteur traite des questions inhérentes à la procédure en proposant un nouveau modèle de résolution des litiges portant sur la garde qui comporte trois étapes. Tout d'abord, l'auteur suggère que la façon dont l'enfant fonctionne au foyer, dans la collectivité et à l'école fasse l'objet d'un affidavit détaillé. Cet affidavit devrait mettre l'accent sur les valeurs de la communauté et la perspective de l'enfant qui serviront à fonder la décision de la cour. En second lieu, l'auteur envisage une médiation effectuée sur le mode du mini-procès, où le juge agit en tant que participant actif dans un contexte non accusatoire. En cas d'échec, le juge président doit se désister en faveur d'un juge indépendant et un procès ordinaire commencera alors.

\section{TABLE OF CONTENTS}

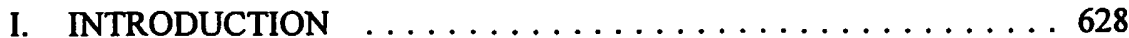

II. CUSTODY DISPUTES IN THE PROVINCIAL COURT . . . . 631

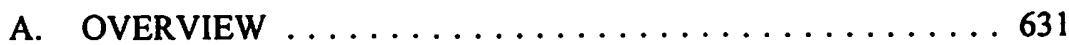

B. THE COURT: A HISTORICAL PERSPECTIVE .......6633

C. THE COURT: A CONSTITUTIONAL PERSPECTIVE ... 637

D. THE BEST INTEREST OF THE CHILD STANDARD $\ldots 640$

E. THE BEST INTERESTS STANDARD:

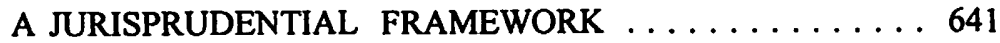

Judge, Provincial Court of Alberta, Family and Youth Division, Calgary, Alberta. This article is in partial fulfilment of the requirements for the Master of Judicial Studies degree program at the University of Nevada, Reno, in co-operation with the National Council of Juvenile and Family Court Judges. 
F. THE BEST INTEREST STANDARD:

A HISTORICAL REVIEW ............... 646

G. CUSTODY APPLICATIONS IN THE

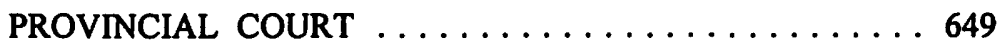

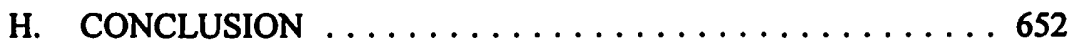

III. A NEW MODEL OF JUDICIAL DECISION-MAKING $\ldots \ldots 653$

A. INTRODUCTION ................. 653

B. STAGE ONE: THE APPLICATION ...........6 658

C. STAGE TWO: JUDICIAL DISPUTE RESOLUTION . . . . 660

D. STAGE THREE: THE TRIAL $\ldots \ldots \ldots \ldots \ldots \ldots \ldots 675$

E. CONCLUSION ....................6 686

\section{INTRODUCTION}

The preamble to the United Nations Convention On The Rights Of The Child recognizes "the family, as the fundamental group of society and the natural environment for the growth and well-being of all its members and particularly children" and that "the child, for the full and harmonious development of his or her personality, should grow up in a family environment, in an atmosphere of happiness, love and understanding." Regrettably, it is now a feature of our social fabric that marriages break down, parents separate, and family restructuring must occur. Inevitably, this often takes place in a court environment. This article examines this process in the Provincial Court of Alberta (the Court) and proposes a new model of judicial dispute resolution to better effect this necessary purpose.

Today, there is a general dissatisfaction with how courts deal with family issues. The Lieutenant-Governor's Conference, Celebrating Alberta Families, stated:

There is a need to assess the impact on families of policies, laws, and programs developed at Federal, Provincial and Municipal levels. Programs, services, and laws must be designed and delivered with the needs and characteristics of families and their social environment at the forefront. $A$ restructured system of family law that reflects current societal needs is critical. ${ }^{2}$

The conference recognized that systems must be responsive to families rather than focus on the legal system.

There is a need for a new Family Law Act and a reconstruction of the legisiation pertaining to family law. Existing proposals in Alberta and elsewhere on support, children and cohabitation need to be reviewed. Action needs to be taken to ensure a unified comprehensive approach to the modern family and a more humane approach to Family law. ${ }^{3}$

Such concern is neither novel nor new. In 1906, Dean Pound noted the causes of dissatisfaction with the legal system: 
(1) the necessarily mechanical operation of rules, and hence of laws;

(2) the inevitable difference in rate of progress between law and public opinion;

(3) the general popular assumption that the administration of justice is an easy task to which anyone is competent;

(4) popular impatience of restraint. ${ }^{4}$

\section{Pound elaborated on his first cause:}

This is one of the penalties of uniformity. Legal history shows an oscillation between wide judicial discretion on the one hand and strict confinement of the magistrate by minute and detailed rules upon the other hand.... Justice, which is the end of law, is the ideal compromise between the activities of each and the activities of all in a crowded world. The law seeks to harmonize these activities and to adjust the relations of every man with his fellows so as to accord with the moral sense of the community. When the community is at one in its ideas of justice, this is possible. When the community is divided and diversified, and groups and classes and interests, understanding each other none too well, have conflicting ideas of justice, the task is extremely difficult. It is impossible that legal and ethical ideas should be in entire accord in such a society. ${ }^{5}$

His second cause was closely related:

In order to preclude corruption, to exclude the personal prejudices of magistrates, and to minimize individual incompetency, law formulates the moral sentiments of the community in rules to which the judgements of tribunals must conform. These rules, being formulations of public opinion, cannot exist until public opinion has become fixed and settled, and cannot change until a change of public opinion has become complete. 6

A significant social movement aimed at reforming legal systems is not new. Tomasic and Feeley recognized that a major concern of proponents of reform has been the development of new and more effective ways to handle so-called small claims and petty criminal offenses:

Responding to long-standing complaints that the courts are overloaded, too costly, and too time consuming to afford ordinary citizens access to justice, and that the formality of the courts precludes them from identifying root causes of interpersonal disputes, and, hence, affecting lasting settlements, a number of reforms have been put forward to simplify and supplement existing legal processes.

[Reformers] have been encouraged by the perception of a crisis in law, calls for delegalization, plans for simplification of legal processes and attacks on professionalism in general. 
The belief that the tegal system has become too complex and unresponsive to meet community needs for justice has led to two types of efforts. One of these has been to simplify and streamline court structures and procedures. The other has involved attempts to remove disputes from the courts entirely by taking them to less formal, more responsive forums. ${ }^{7}$

These thoughts resonate with anyone connected to family law. The success of the alternate dispute resolution movement is seen as an answer to the perceived inadequacies with our court system. Again, Tomasic and Feeley suggested that this is not a new phenomenon:

Historically we have seen the pendulum of legal change swing from poles such as formality and informality, complexity and simplicity, professionalism and lay decision making, adversary and inquisitorial approaches, and the poles of greater and lesser concern for individualization. Indeed these fluctuations reflect tensions inherent in the law itself, expressing as it does a multiplicity of conflicting and competing goals.

They concluded that the current embrace of informality (in 1982) is part of this "historical ebb and flow."

Presently, a general perception persists in Alberta of how the Court deals with its jurisdiction in family matters: it muddles through. There is no uniform process nor established guideline to aid litigants, lawyers, involved professionals and judges in the application of the best interest standard in child custody cases. While the Court gets the job done, litigants do not feel part of the process and often do not understand how the Court reaches decisions affecting their future and that of the child.

While it is not the place nor function of judges to advocate law reform, it is the right and obligation of judges to deal with these perceptions and ask questions about the adjudicatory process. In the present era of fiscal restraint everyone is expected to do more with fewer resources. Restructuring is taking place, and courts must be part of this as they are accountable to the public they serve. The Court, as master of its own house, can better serve its own process by becoming more accessible, more efficient and more educational, so the public can learn how to deal more appropriately with family problems. If court adjudication is necessary, the process should be a guide for the parties and the court, so the judges may give well-reasoned judgments. In sum, there should be a melding of procedural law with substantive law to enable the Court to bring law to every person's door.

The Court must define itself. The foundation for the Court's custody jurisdiction is s. 32 of the Provincial Court Act. ${ }^{10}$ A more spartan empowering section of legislation is hard to imagine. The best interests of the child standard is the sole criteria for

R. Tomasic \& M. Feeley, Neighbourhood Justice: Assessment of an Emerging Idea (New York: Longman Inc., 1982) at ix.

lbid. at $\mathrm{x}$.

Ibid. at $\mathrm{x}$.

so The Provincial Court Act, R.S.A. 1980, c. P-20 [hereinafter the Act]. 
decision-making, unadorned with further specificity. This article examines how the Court deals with the law in day-to-day practice with a view to reforming the process.

There is no need for the Court to await legislative change. The Court must accept the existing mandate of the legislature of Alberta and put into practice a procedural model designed to effect the very purposes and goals reformers advocate on the issues of custody and access.

\section{CUSTODY DISPUTES IN THE PROVINCIAL COURT}

\section{A. OVERVIEW}

Albertans unable to resolve their disputes without external assistance have a choice of courts in Alberta. Custody dispute adjudication may take place in the court of general jurisdiction, the Court of Queen's Bench, or in the limited jurisdiction court, the Provincial Court of Alberta. While the substantive law applied is the same, namely, the best interests of the child standard, there is a difference in the adjectival law applied. Thompson addressed three adjectival law models: the full scale adversary model, the summary administrative model, and the inquiry model."

The full scale adversarial model is well-known to anyone familiar with criminal trials. Litigation in the Court of Queen's Bench applies this model, with varying degrees of rigour, depending on the nature of the case, counsel, and the judicial control exercised. The adversarial model employs the Rules of Court and applies the common law of evidence. Due process is a hallmark. This model is party driven. The parties decide how to prepare and present their case to the judge.

The summary administrative model expedites process by minimizing technicalities. Two assumptions underlie the summary administration model:

first, neither the value of the interests at stake to the private parties nor the value of those interests to society as a whole is large enough to carry the costs of a full investigation and presentation for the parties...; and, second, there are a large number of relatively repetitive cases where the risk of erroneous decision is not significantly altered by truncated procedures and trials. ${ }^{12}$

The second rationale recognizes that the formalities of the adversarial model are not always needed in family disputes and a summary procedure permits their speedy resolution, hopefully advancing the child's best interests. Thompson called this "the small stakes branch" or the "simple cases branch." ${ }^{13}$ Pleadings are straightforward, there is little room for pre-trial manoeuvring, and cases are considered in busy docket courts. Informal procedures are encouraged. Where the adversarial model leaves process control to the parties, the summary administrative model introduces a specialist judge

$12 \quad$ Ibid. at 26.

$13 \quad$ Ibid. 
to the proceedings, familiar with the issues and the process. The range of evidence is generally narrow, and the judge takes an activist role. A rationale for this "get to the merits" procedure is "the traffic can neither bear the cost nor the time." 14

This summary procedure model promotes conciliation, avoiding competitive, adversarial conflict. In most family disputes, the parties are the parents of children who will be involved with each other as long as they are parents. A conciliatory approach to problem solving is thought to be more appropriate than the competitive model used in adversarial proceedings. Thompson found this model more open to procedural modification than the rigorous full-scale adversarial model, since its goal is "fundamental fairness rather than strict due process."15

Thompson's third model, the inquiry model, "stresses a more individualized, futureorientated, predictive and planning nature of the decision ... compared to the simpler adjudication of past acts,"16 a characteristic of the adversarial model. The inquiry model tribunal controls the process; the parties before the tribunal have a status akin to that of intervenors. Safeguarding the rights and interests of the stakeholders through due process control is of less concern to the tribunal than achievement of the best possible outcome.

What model operates in the Family Court? Allard asked this question in 1972:

What is a Family Court? The general response to the term is that it is some vaguely defined special court that is good for the community. To the legal profession it is known to a few practitioners in each community where Family Courts operate, but its purpose, jurisdiction, procedure and problems are widely unknown. The Family Court is better known to welfare personnel, but on the narrow basis of maintenance orders and integration with child welfare and delinquency matters. To the persons appearing in the Court, a clear process is often not perceived - each participant pressing for his own needs and often feeling aggrieved.

A definition of Family Court is difficult due to many variations and vague legislative descriptions. The common basic structure is a court of summary procedure. ${ }^{17}$

In the first section of this part, this article deals with the Court's family jurisdiction from a historical and constitutional perspective. In the second, it discusses the standard test for decision-making on custody matters - the best interests of the child. In the third section, it takes a functionalist approach to the workings of the court in custody cases. This article maintains that the summary procedure model is well suited for the adjudication of custody disputes in this Court.

Reference Re Section 6 of the B.C. Family Relations Act, [1982] I S.C.R. 62, Estey J. [hereinafter Re B.C. Family Relations Act].

Thompson, supra note 11 at 26.

lbid. at 27.

H.A. Allard, "Family Courts in Canada" in M. de Costa, ed., Studies in Canadian Family Law (Toronto: Butterworths, 1972) 1 [emphasis added]. 


\section{B. THE COURT: A HISTORICAL PERSPECTIVE}

There is a long tradition in Anglo-American law of bringing law to the people. This is the central reason for the creation of the summary procedure courts. While their jurisdiction may be limited, these courts and their development are of the first importance to the people. ${ }^{18}$ The genesis for this Court was the justice of the peace. ${ }^{19}$ The emergence of the justice of the peace, along with the rise of the lower court system in England, began when the sovereign appointed sheriffs to keep the peace. Sheriffs represented the Crown in local public affairs. They were responsible for administering the lower courts of the day and for conserving the peace of the shire. While a sheriff could arrest, try, and imprison some offenders, ultimately he was unable to deal effectively with wide spread unrest in England during this period. ${ }^{20}$ To support the sheriff and his peace-keeping efforts, reliable men were selected in each county to help him enforce the law. These men became known as keepers of the peace and were drawn from the local gentry under Crown appointment. ${ }^{21}$

Early in the 14th century the keeper of the peace superseded the sheriff in both power and influence. Under commission from the Crown, the keeper could not only execute police powers of arrest and imprisonment but also exercise administrative authority over civil matters, such as weights, measures and the standard of coinage. The Statute of Westminster, 1327 formally recognized the office of Keeper of the Peace and established that keepers would be appointed under Crown commission to carry out their duties in the shires. ${ }^{22}$ The Statute of Westminster, $1361^{23}$ confirmed the office of Justice of the Peace and established the office as an institution, thus developing the machinery of the lower court system. Appointments to this office were made by way of recommendations from men of position, although it was the Lord Chancellor who determined the ultimate composition of the commissions. The fundamental legal authority for justices of the peace was derived, first, from the terms of the commission under which they were appointed, and second, from the plethora of statutes that the justices were charged to enforce.

It is commonly thought that justices of the peace had only a criminal jurisdiction. ${ }^{24}$ Statutes, however, developed civil and administrative jurisdiction. ${ }^{25}$ While property disputes remained beyond their scope, as justices an extraordinary range of administrative responsibilities were placed on them. ${ }^{26}$ These men were charged with inspecting bridges, highways, and sewers; administrating pool laws and the collection

J.W. Hurst, The Growth of American Law: The Law Makers (Boston: Little Brown, 1950) at 148. I am indebted to Ms. Rhonda Elder, for her unpublished manuscript, "Justices of the Peace and the Development of the Lower Court System in England: An Overview."

T. Skyrme, History of the Justice of the Peace: Vol. 1: England to 1689 (Chichester, England: Barry Rose, 1991) at 2.

Ibid. at 5-14.

Ibid. at 15.

(U.K.), 34 Edw. 3, c. 1.

Hurst, supra note 18 at $147-48$.

Skyrme, supra note 20 at 138.

See generally M. Dalton, The Country Justice (London: H. Lintot, 1727). 
of tithes; regulating transportation, wine, wax, and watermelon; licensing ale houses, and appointing sheriffs in the country. In carrying out their duties then, justices became quite literally the governors of their communities. Modern administrative tribunals spring from this historical base.

Justices could sit singly or in groups of two or three depending on the task they were to perform. Under commission by statute, for example, a justice sitting alone had summary jurisdiction over certain local matters. Since the procedure to be followed and exercised in their duties was not prescribed by statute, justices developed an informal practice by which, dividing the county into small districts, two or more justices of each district gathered regularly to perform their judicial administrative functions. By the 18th century, these meetings were formalized into what were called petty sessions. Though never formally recognized by statute, petty sessions grew to become an essential part of the local justice machinery. Thus English justices of the peace became the workhorses of the English common law "who made local government work."27

When England colonized North America, the firmly established legal machinery of its court system, composed of both superior and local tribunals, was transported to the New World. While legally trained men administered the Royal Courts of the Crown, quarter, general and petty sessions operated under the hand of local citizenry drawn from communities to serve as justices of the peace. A local court could effectively administer law at the community level as it had an appreciation for the nature and needs of the local population. This local court system became part of the Canadian judicial system.

The American tradition is a second historical feature of the justice of the peace system that plays an important part in the Provincial Court's existence and function. While the judicial office of justice of the peace was transferred to America, its character in the United States soon altered. ${ }^{28}$ During reconstruction after the Civil War, American society changed rapidly. Industrialization occurred. With increased immigration people moved westward, spurred on by the doctrine of manifest destiny. Urbanization took hold. These events created new problems for the administration of justice: employment issues, landlord and tenant disputes, creditor-debtor matters. Separations in families occurred giving rise to support issues and custody disputes. Delinquency was an offshoot of rapid growth. New regulatory issues flourished in this industrial age. American legislators formed new courts to deal with these issues, creating, in Hurst's words, "a crazy quilt of inferior courts, wherever city growth had pressed hard on old institutions."129

The creation of juvenile domestic relations courts is significant for this article since this Court's family jurisdiction springs from these origins. It is important to understand 1954) at 227.

28 See generally Hurst, supra note 18 at 147-69. 
the creation of family courts in the United States from a historical perspective. Mintz comprehensively dealt with this family law history and discovered:

A wide spread sense of dissatisfaction accompanying the proliferation of litigation over the family. Critics charge that family law decisions are too unpredictable and arbitrary, that family law judges exercise excessive discretion; that our present system of family law generates too much litigation and that legal concepts like "the best interests of the child" are so broad and undefined that they allow jurists to impose their own moral preferences in their rulings. ${ }^{30}$

Mintz found two perspectives in this public debate about family law." The everincreasing judicial intervention in the family was seen as a cause for the erosion of the community. Every complaint was seen as a conflict of rights to be adjudicated. In contrast, the judicial concern with privacy and individual rights was seen as inevitable and positive as it reflected a growing concern for these rights. This also reflected changes taking place in society, all of which generated conflicts requiring court adjudication. Mintz saw these historical developments contradicting each other yet each occurring at the same time: "One involves a gradually growing emphasis on privacy and individual rights; the other, a gradual increase in the involvement of the legal system in the internal functioning of families." ${ }^{132}$ Mintz's look at the history of family law demonstrated the changing relationship of the state and the family, so that "through law, government has helped socially construct what Americans mean by family." ${ }^{33}$

By the 19th century, many public and private institutions developed an interest in helping solve family problems, understanding that family dysfunction was closely related to social dysfunction. This reform movement created "substitute families such as public schools, houses of refuge, reform schools, YMCAs for young rural migrants to cities, orphanages and penitentiaries. ${ }^{.34}$

Taken together, these precedents enacted a shift from the authority of the head of the home, the patriarch, to appointed or elected judges who were given "broad discretionary authority to interpret the law, investigate the moral fitness of parents and act in children's supposed best interests. ${ }^{135}$ By the late 19th century, a shift had occurred in that legal priorities moved from individual choice to social control. ${ }^{36}$

In a Canadian study paralleling Mintz's description of the reorientation of American family law, Chunn described the Canadian situation:

Like their American counterparts, Canadian middle class leaders became increasingly concerned from the late nineteenth century onward, about the issue of how to fashion a stable social order out of the

S. Mintz, "Children, Families and the State: American Family Law in Historical Perspective" (1992) 69 Den. U.L. Rev. at 635.

lbid. at 635-36.

Ibid. at 636.

Ibid. at 637.

Ibid. at 746.

Ibid. at 647 .

lbid. 
seeming chaos generated by rapid urbanization, industrialization and political enfranchisement of the working population. Their intensive search for ways of enforcing middle class standards of hygiene, education and morality among the working and dependent poor, now concentrated in the cities, produced a focus on the family as the key to social integration. ${ }^{37}$

Legislatures enacted laws relating to child protection, desertion, and delinquency "with the aim of enforcing middle class conceptions of childhood and family life through the regulation of intra-familial relations." ${ }^{38}$ Many of society's most intractable social problems originated in deformed or dysfunctional homes, and it became necessary to expand the role of the state as supervisor and administrative authority over the family. In both Canada and the United States, a new therapeutic concept of family law emerged which reflected "a growing conviction that courts could solve domestic problems"39 and "[t]his new legal ideology involved a view of all children - not simply poor and delinquent children - as wards of the state." 40

This is the essence of the Progressive Era that was responsible for the creation of the first family courts. Family courts were to provide an informal and less adversarial forum than the criminal courts for a broad range of family problems including desertion, divorce, child neglect, maltreatment, and juvenile delinquency. Family court judges, helped by professional staffs of psychologists, social workers, and probation officers, now settled domestic conflicts and reconciled marriage partners. Such disputes required a social approach which police magistrates were rarely willing or able to apply because they devoted most of their time to criminal cases and procedures. The solution, then, was to create a special court in a separate building away from both police and other criminal courts: "Socialized tribunals," where magistrates had the power to relax the usual rules of evidence and make judgments "in accordance with the social needs of the family" and where trained workers could mediate out-of-court settlements, would be far more conducive to domestic reconciliation than litigious hearings. ${ }^{41}$ Domestic relation courts, so the reformers said, would save money. Litigants could come to court without counsel; there would be no costs and no occasion for pleadings. Like the justices of the peace system, this court created its own procedure to carry its purposes. Chunn summarizes the commencement of the domestic courts in Ontario:

The early proponents of family courts in Ontario viewed themselves as guardians of the nuclear family and were imbued with the same benign conception of social control through social engineering so eloquently espoused by American progressives and propagated in the sociological jurisprudence of Roscoe Pound. ${ }^{42}$

Whatever the rhetoric of the progressive movement, Chunn asserts that these socialized courts (Juvenile and Family Courts in Ontario) revealed themselves to be

D. Chunn, "Regulating the Poor in Ontario: From Police Courts to Family Courts" (1987) 6 C.J.F.L. 85 at 86.

lbid. at 86.

Mintz, supra note 30 at 659 .

Ibid. at 650.

Chunn, supra note 37 at 88.

Ibid. at 90. 
remodelled versions of the police tribunals that they were meant to replace. Despite the reformers' assertions, delinquency and non-support continued to flourish.

Allard notes the continued existence of this dual court system, citing Justice Minister John Turner's remarks, in 1969:

And so one may find two separate systems of family law - the family law of the rich, created, developed, and administered by the courts, and the family law of the poor, as public law, administered largely through provincial or state or local non-juridical agencies.... These agencies are sometimes more concerned with minimizing the cost of relief than maximizing the rights and interests of the recipients. $^{43}$

Chunn asserts juvenile and family relations courts perpetuated this two-tiered system of family law; family matters involving the marginalized in society were processed in the lower courts and those of the propertied classes in the higher courts. However, a significant distinction emerged. These

[N]ew courts proved superior to the police courts in their ability to regulate intra-familial relations among the poor in an urbanized, industrialized, mass society. This "success" guaranteed not only their continued existence but also their proliferation in the aftermath of World War II. ${ }^{4}$

Such was the case in Alberta when the Legislature created family courts in Edmonton and Calgary in 1952 and 1953.

\section{THE COURT: A CONSTITUTIONAL PERSPECTIVE}

This is a court of limited and specific jurisdiction because of constitutional limitations. Section 92(14) of the Constitution Act, $1867,{ }^{45}$ allocates to the provinces the power to make laws in relation to the administration of justice. It expressly includes the constitution, maintenance, and organization of provincial courts, both of civil and criminal jurisdiction, with procedure in civil matters in these courts. The Constitution recognizes that, at Confederation, each province had its own system of courts modeled on the English system. This system included what have been called superior courts, or courts with general jurisdiction, and limited jurisdiction courts, the so-called inferior courts. ${ }^{46}$ Section 129 of the Constitution expressly contemplates continuation of the limited jurisdiction courts. Thus, their organization and jurisdiction remain the responsibility of the provinces.

As provincial courts proliferated, it became obvious that a legal distinction had to be articulated on the jurisdictional limits of both these courts. Jurisprudence has arisen

Allard, supra note 17 at 8 quoting Canadian Press (2 December 1969).

Chunn, supra note 37 at 102 .

(U.K.), 30 \& 31 Vict., c. 3.

I dismiss, for palpable reasons, this anachronistic description of courts. If used today, it suggests there is a qualitative difference in these courts, a position from which I resile. Hence my appellation to describe the difference between a s. 96 court and a s. 91(14) provincial court will be a general jurisdiction court and specific or limited jurisdiction court. 
over the years providing tests to determine whether a particular function exercised by a court was a s. 96 function and not within the purview of the limited jurisdiction court. ${ }^{47}$

The Supreme Court of Canada, in the Adoption Reference, decided the validity of four statutes concerning adoption, neglected children, illegitimate children and deserted wives. This social legislation was cast into constitutional doubt because each statute conferred a new jurisdiction on the limited jurisdiction court presided over by provincially appointed officials. Duff C.J.C., in upholding the grant of jurisdiction, decided s. 96 contemplated the existence of limited jurisdiction courts, whose judges would be appointed and paid by the province and that this jurisdiction was not frozen at Confederation. The provinces could broaden the jurisdiction of these courts when it remained within the competence of the provinces. This jurisdiction must broadly conform to the type of jurisdiction generally exercisable by courts of summary conviction rather than that exercised by the general jurisdiction courts. The Supreme Court decided that the provisions for making adoption orders, enforcing maintenance obligations for wives and children, and child protection and juvenile delinquency matters, were analogous to the traditional jurisdiction exercised by the justice of the peace. ${ }^{48}$

The Privy Council reviewed this test in John East Ironworks and noted that if the same test were presented to the Law Lords "they might well answer it in the same way, for at least from the earliest times the administrative and judicial duties of the Justices of the Peace have been curiously blended: that feature, a court of summary jurisdiction, has in common with the appellant board. ${ }^{49}$ The Privy Council worded the test differently in John East Ironworks: does the jurisdiction of the Board broadly conform to the type of jurisdiction exercised by the s. 96 courts?

The Supreme Court of Canada, in 1981, dealt with the impact of s. 96 on the creation of provincial administrative tribunals in Residential Tenancies. Dickson J., as he then was, suggested a three-step approach to the resolution of a s. 96 challenge to an administrative tribunal's powers. The first step is a historical inquiry into the impugned power: does it "broadly conform" to the power exercised by a superior, district or county court at Confederation? The second step, reached only if the answer to the historical inquiry is yes, is an inquiry into whether the impugned power is a judicial power. If the answer is in the affirmative, then the third step is an inquiry into whether the power, in its institutional setting, has changed its character sufficiently to negate the broad conformity with superior, district or county court jurisdiction. ${ }^{50}$

A useful compendium of case law defining this issue includes these cases: Reference Re Adoption Act, [1938] S.C.R. 398 [hereinafter Adoption Reference]; Sask. Lab. Rel. Bd. v. John East Ironworks Lid., [1948] 4 D.L.R. 673, [1949] A.C. 134 (P.C.) [hereinafter John East Ironworks]; Rejerence Re Residential Tenancies Act, [1981] 1 S.C.R. 714 [hereinafter Residential Tenancies]; Re B.C. Family Relations Act, supra note 14; and Reference Re Young Offenders Act, [1991] 1 S.C.R. 253. 
A noteworthy addendum to the first step of historical inquiry is the finding, in Residential Tenancies, that the impugned power must have been within the exclusive jurisdiction of s. 96 courts at Confederation. If there was concurrent jurisdiction in a limited jurisdiction court or tribunal at Confederation, then the tribunal will pass the historical test."

Residential Tenancies described a judicial power as one that involves a private dispute between the parties, that must be adjudicated through the application of a recognized body of rules, and that must be adjudicated in a manner consistent with fairness and impartiality. ${ }^{52}$

The third step, the institutional setting inquiry, examines the power in its institutional setting to see whether it still broadly conforms to a s. 96 power. To be constitutionally valid, the power must be ancillary to a predominately administrative function or legislative scheme or necessarily incidental to such function. ${ }^{53}$

In Re B.C. Family Relations Act the Supreme Court followed the Adoption Reference and upheld the provincial court's jurisdiction over guardianship and custody, reasoning that once adoption has been admitted to be within the limited jurisdiction court's power, the included orders of custody and access should not be treated differently. ${ }^{54}$ However, the court struck down provisions permitting the provincial court to make orders with respect to occupancy of and access to the family home, as this power was more conformable to that exercisable by a s. 96 court. This kind of remedy involved adjudication of proprietary rights and granting of injunctive relief.

In Reference Re Young Offenders Act, the Supreme Court again followed the threestep approach. The Court held that Youth Courts were validly constituted provincial courts, though there was no comparable historical connection. The summary nature of the proceedings in this court allied this court's jurisdiction to that of existing provincial courts, and this met even the minority opinion test of novel jurisdiction. The Young Offenders Act was a distinct legislated response to a new social problem of youth crime and rehabilitation. ss $^{\text {a }}$

It follows then, if there is to be any modification of the procedures used in the provincial family courts, the essential character of this court must not change. The new procedure cannot take on the appearance of the general jurisdiction court with all its adversarial procedures.

Ibid. at 734 .

lbid. at 734-35.

Ibid. at 735-36.

Re B.C. Family Relations Act, supra note 14 at 112-13.

See generally Reference Re Young Offenders Act, supra note 47. 


\section{THE BEST INTEREST OF THE CHILD STANDARD}

The Anglo-American community accepts a fundamental principle concerning the private ordering of families: parental guardians have the right and duty to raise their children as they will, free from state intervention or intervention by third party strangers, absent compelling reason. The core family legislation in the Province of Alberta, the Domestic Relations $A c t,{ }^{56}$ declares the birth mother a parental guardian, and the biological father, in specified circumstances, a guardian with her: if he were married to her at the time of birth, married her before the birth of their child, married her after the birth of their child, or cohabited with her for a continuous period of one year prior to the birth of their child. ${ }^{57}$ Parental guardians are our preferred social arrangement for the rearing and protection of children. This procreational model favours married mothers and fathers and their dependent children. While other models may be created by adult choice, there is no necessary obligation for society to recognize, let alone promote, these models as more desirable than the procreational model.

While it is convenient for many to discuss legal issues in terms of rights, the correlation between rights and responsibilities must not be forgotten; one cannot exist without the other. ${ }^{58}$ Thus it is with the raising of children. Parental guardians are granted the freedom to raise their children as they deem appropriate. In recognizing the principle of family autonomy, legislatures say this is the best way to rear children and to transmit social values from generation to generation. ${ }^{59}$ The family is seen as the principle conservator and transmitter of cherished values and traditions. Any invasion of the sanctity of the family, even with the loftiest of motive, unavoidably threatens these traditions and values. ${ }^{60}$

Marriage breakdown has been recognized in society for many years in one form or another, yet most child-centred issues of the family have been resolved by the family, not by courts. ${ }^{61}$ In the small number of cases reaching the courts for resolution, the standard employed in England, Canada, and the United States has been the best interests of the child. Becker notes the legal community has relied on this standard to guide the development of family law on child issues. In a homogeneous society

when a cultural consensus of marriage-till-death prevailed, when divorce, if not rare, was uncommon, most child-centred issues were resolved in the family rather than in court. Society had little need to

Domestic Relations Act, R.S.A. 1980, c. D-37.

Jbid., s. 47.

See B.(R.) v. Children's Aid Society of Metro Toronto (1995), 9 R.F.L. (4th) 157 at 207 (S.C.C.), La Forest $J$.

See Premier's Council: In Support of Alberta Families, Coming of Age in Alberta, An Overview of Parents' and Children's Rights and Responsibilities (1994). 
challenge, define, or amplify the legal "best interests" standard. Affected were the few, not the many. ${ }^{62}$

The family has undergone a fundamental transformation because of the divorce revolution. ${ }^{63}$ Already well under way in the 1960 s in the United States, the revolution in Canada began when Parliament passed The Divorce Act, 1968. Marriage break-down, separation, and divorce were now part of the social fabric. In consequence, more custody cases came before the courts for resolution when parental guardians failed to find their own solutions. The consequence of this phenomena has been to place the best interests of the child standard at the forefront of the legal and social dialogue. There is a general dissatisfaction with this standard, both in the social framework literature and in legal doctrinal thought.

Reviewing the best interests of the child standard against this backdrop, Pound's third reason for popular dissatisfaction with the administration of justice should be recalled. Pound recognized the popular assumption that the administration of justice is an easy task where anyone is competent. ${ }^{64}$ Rather, it is anything but easy to decide what is best for a child. Indeed, it is quite impossible to render a general definition. Best interest is a jurisprudential standard understood within the context of existing social thought. This can be discerned from a synthesis of case reports, social science literature, and popular commentary. The best interests of the child standard is not something that is weak and indeterminate, as many critics suggest. It is a positive force that permits individualized treatment of a family issue requiring resolution by a judge in a court of law; namely, a judge who is an experienced professional, learned in the law, bound by ethical training, vetted by judicial council, chosen from many, independently serving the public, and yet still accountable through appellate review.

\section{E. THE BEST INTERESTS STANDARD: A JURISPRUDENTIAL FRAMEWORK}

Custody disputes in the Court must be decided according to the best interest of the child standard, something decidedly different than the best interests of the parents. The Legislature has not adopted criteria for best interests and has left it to the Court to decide the meaning of this phrase at a given time and place. This social policy choice prefers flexibility, obtained through case by case law development, over fixity, reached through the application of rules. Despite a robust literature on best interests of the child suggesting further restrictive criteria, within a legalistic framework, this standard remains the sole measure for judicial decision-making. ${ }^{65}$ In Canada, Morden J.A. states the fundamental reason, in a parental mobility case, Carter v. Brooks:

Ibid. at 568.

For an overview of this fundamental change and the ramifications for children, see B.D. Whitehead, "Dan Quayle Was Right" The Atlantic (April 1993) 47 and B.D. Whitehead, The Divorce Culture (New York: Alfred A. Knopf, 1997).

Supra note 4 at 357.

See generally Young v. Young (1994), 49 R.F.L. (3d) 117 (S.C.C.) [hereinafter Young]; and Gordon v. Goertz (1996), 196 N.R. 321 (S.C.C.) [hereinafter Gordon]. 
As far as the state of the law is concerned, the proper course now, to make it clear that the only principle that governs is that of the best interests of the child.... What guidance can be given for the application of the best interests of the child test? This area of the law is no different from many others where, in the application of a broad legal standard, what is desired is both predictability of result and justice to the parties based on the particular circumstances of the case. It is often difficult to ensure by "rules" that both objects are met. If the rules are too precise, it may be that important circumstances in some cases will be left out of account in applying the governing tests and justice will suffer. On the other hand, if there are not certain common understandings on how the issue is to be approached, the danger is one of undue subjectivity, with the consequence of reduced predictability of result.

\begin{abstract}
Having regard to the foregoing, I am satisfied that the best interests test cannot be implemented by the devising of a code of substantive rules, even if this could be done within the confines of a single case. It may be thought that it could be satisfactorily carried out by procedural or evidential rules embodying presumptions and onuses.... With respect, I find none of these approaches to be particularly satisfactory. I am skeptical that general rules that do not admit of frequent exceptions can evenly and fairly accommodate all of the varying circumstances that can present themselves.... I think that the preferential approach in the application of the standard is for the court to weigh and balance the factors which are relevant in the particular circumstances of the case at hand, without any rigid preconceived notion as to what weight each factor should have. I do not think that the process should begin with a general rule that one of the parties will be unsuccessful unless he or she satisfies a specified burden of proof. This over-emphasizes the adversary nature of the proceeding ... parents should bear an evidential burden. At the end of the process, the court should arrive at a determined conclusion on the result which better accords with the best interests of the child. ${ }^{66}$
\end{abstract}

The Supreme Court has upheld this individualized approach and made clear this test is child-centred: the child's best interest is the sole consideration. ${ }^{67}$

The reality of family law today is that family problems are "polycentric" - a term introduced by Polanyi. ${ }^{68}$ Polycentric problems are many-centred. Fuller described this concept through the metaphor of a spider's web: "Pull a strand here, and a complex pattern of adjustments runs through the whole web. Pull another strand from a different angle, and another complex pattern results." ${ }^{69}$ How the courts deal with family law issues involves the family's social, economic, cultural, and legal relationships. An essential feature of this web is how a judge decides the case. Because of the complexity and polycentric nature of custody disputes, this concept introduces the role judicial discretion plays in applying best interests to resolve the dispute. The best interests of the child standard is synonymous with the term judicial discretion.

Many find judicial discretion all-powerful and seek its curtailment, through guidelines or presumptions, and preferably by rule. Long ago, Lord Camden described a form of discretion:

Carter v. Brooks (1991) 30 R.F.L. (3d) 53 at 61-63 (Ont. C.A.) [emphasis added]. See Gordon, supra note 65. M. Polanyi, The Logic of Liberty: Reflections and Rejoinders (Chicago: University of Chicago Press, 1951) at 170.

L.L. Fuller, "Collective Bargaining and the Arbitrator" (1963) Wisc. L. Rev. 1 at 33. 
The discretion of the judge is the law of tyrants; it is always the known; it is different in different men; it is casual, and depends upon constitution, temper and passion. In the best it is often times caprice, in the worst it is every vice, folly and passion which human nature can be liable. ${ }^{70}$

Judicial discretion is sometimes described as "Khadi-discretion." 1 The decision by King Solomon, in his famous child custody case, is a prime example of Khadi justice. Khadi justice is:

Adjudication of a purely ad hoc sort in which cases are decided on an individual basis in court and in accordance with an indiscriminate mixture of legal, ethical, emotional and political considerations ... Khadi justice is irrational in the sense that it is peculiarly ruleless, and makes no effort to base decisions on general principles, but seeks, instead, to decide each case on its own merits and in light of unique considerations that distinguish it from every other case. ${ }^{72}$

Unfettered discretion is Khadi discretion. By contrast, Cardozo J. defined appropriate judicial discretion:

The judge, even when he is free, is still not wholly free. He is not to innovate at pleasure. He is not a knight-errant roaming at will in pursuit of his own ideal of beauty or of goodness. He is to draw his inspiration from consecrated principles. He is not to yield to spasmodic sentiment, to vague and unregulated benevolence. He is to exercise a discretion informed by tradition, methodized by analogy, disciplined by decision, and subordinated to "the primordial necessity of order in the social life". Wide enough in all conscience is the field of discretion that remains. ${ }^{73}$

Context is important when we apply the best interests standard because it is the nature of law to balance between two (or more) valid, competing social policy interests. The task of balancing requires the law choosing between fixity and flexibility. For example, when we look at the strand of family law dealing with child protection issues, we recognize, in limited circumstances, that the state does have a right to intervene in the private life of the family if compelling reasons exist. When the law permits such state intervention, the modern view is to prescribe ways to effect such purposes so fixity results. We wish to control state intrusion into family autonomy through rules. However, recognizing family autonomy in situations such as child custody disputes, where private family issues arise for court resolution, the law permits discretion as flexibility is desired, which the court applies through the discretionary standard, the best interests of the child. Paton points out that "[m]odern juristic analysis shows law operating through a continuum of principles, standards, concepts, and rules. ${ }^{174}$ When the law needs flexibility, the law prefers principles and standards. If fixity is required, the law prefers concepts and rules.

B. Overton, "The Meaning of Judicial Discretion" in J.E. Smithburn, ed., Judicial Discretion, (Reno, Nev.: National Judicial College, 1991) 1 at 3.

C.E. Schneider, "Discretion, Rules, and the Law: Child Custody and the U.M.D.A.'s Best Interests of the Child Standard" (1991) 89 Mich. L. Rev. 2215 at 2242.

Jbid. at 2243.

Quoted in Smithburn, supra note 70 at 47.

G. Paton, A Textbook of Jurisprudence, 4th ed. (Oxford: Clarendon Press, 1964) at 236. 
A principle is a bedrock reason for a rule of law. Through principles law grows making law more than a codification of rules. A standard provides elasticity to law. For example, Paton set out the well-recognized principle - a driver on the highway owes a duty of care to prevent injury to others. To apply that principle, we use the standard of reasonable care. This is the essence of the law of negligence. When you invoke this element, there is room for differences of opinion. Reasonableness can only be decided by analyzing the application of a wide standard to the facts of a given case. To a degree, indeterminacy can result. Many decisions are necessary to work out the real meaning and proper application of the principle and standard. ${ }^{75}$

At the other end of the continuum are legal rules and concepts. Paton describes a concept as an abstraction from particular themes or events forming a general notion that is man made. The purpose of a concept is to help in the classification of things. For example, a document is a bill of exchange or it is not. We define what a bill of exchange is. Once so classified, we need only make a factual finding to complete the concept. A rule is precept laying down a specific concept resulting from specific facts. $^{76}$

Dworkin sets out these basic themes in an understandable way. ${ }^{77}$ He notes that the difference between rules and principles is a logical distinction:

Both ... point to particular decisions about legal obligation in particular circumstances but they differ in the character of the direction they give. Rules are applicable in an all-or-nothing fashion. If the facts a rule stipulates are given, then either the rule is valid, in which case the answer it supplies must be accepted, or it is not, in which case it contributes nothing to the decision. ${ }^{78}$

Dworkin uses the rules of baseball to demonstrate his point. In baseball, it is a rule that if the batter has three strikes he is out. Therefore, an umpire cannot consistently say that this is an accurate baseball rule yet still decide that a batter who has had three strikes is not out. The rule may have exceptions. If the catcher drops the ball on the third strike, the batter is not automatically out. In order to be fair, when we state the rule, we must also state its exceptions because to do otherwise would suggest incompleteness, if not inaccuracy. ${ }^{79}$

Dworkin says this is not the way principles operate. With principles, legal consequences do not follow automatically when the conditions provided for are met. Dworkin makes the point using the well-known principle: "no man may profit from his own wrong." This is a principle because we do not mean the law never permits a man to profit from the wrongs he commits. Dworkin realizes people often profit legally from their legal wrongs, and proves this by the example of adverse possession. Dworkin explains that principles "state [a] reason that argues in one direction, but does not 
require a particular decision." ${ }^{80}$ A principle of law is one that, in particular circumstances, the judge must consider if it is relevant, as it inclines the decision-maker in one direction or another. Dworkin also uses the concepts of weight and importance to demonstrate the difference between rules and principles. Principles have these dimensions, rules do not. When principles intersect, we must resolve the conflict by considering the relative weight of each. When two rules conflict, only one is a valid rule, and therefore only one can prevail.

It follows that principles require substantial elaboration if they are to be used to decide cases. Principles are abstractions that provide a purpose or objective yet still leave the decision-maker the task of figuring out how to achieve that objective and the weight accorded that principle when other principles point in other directions. ${ }^{81}$ As the decision-maker moves from rule to principle in this continuum, the discretion afforded the decision-maker increases. Dworkin classifies discretion in three ways:

(1) a "weak" version, suggesting only that the decision maker must exercise judgment and choose; (2) a second "weak" version, reflecting the degree to which the decision maker's choice will be subject to review or modification by others; and (3) a third, "strong" version present when a judge is not controlled by a standard, that is to be applied. ${ }^{82}$

Mnookin suggests that in applying the best interests of the child standard, a judge exercises discretion in Dworkin's strong sense. ${ }^{83}$

Since discretion is a relative idea, it must be considered in a context to be properly understood. Dworkin's defining conclusion captures the essence of judicial discretion: "Discretion, like the hole in a doughnut, does not exist except as an area left open by a surrounding belt of restriction. ${ }^{18}$ Discretion is always coloured by the background of understood information against which it is used. Dworkin suggests a positivist would argue that principles cannot count as law because their authority, and even more so their weight, are "congenitally controversial." ${ }^{85}$ Dworkin's answer is worth remembering:

It is true that generally we cannot demonstrate the authority of weight of a particular principle as we can sometimes demonstrate the validity of a rule by locating it in an act of Congress or in the opinion of an authoritative court. Instead, we make a case for a principle, and for its weight, by appealing to an amalgam of practice and other principles in which the implications of legislative and judicial history figure along with appeals to community practices and understandings. There is no litmus paper for

so Jbid. at 26.

st See H.L.A. Hart \& A. Sacks, "The Legal Process" (1958) (unpublished manuscript in the Harvard Law School Library) cited in R.H. Mnookin, "Child-Custody Adjudication: Judicial Functions in the Face of Indeterminacy" (1975) 39:3 L. \& Cont. Probs. 226 at 231. Mnookin, ibid. at 231.

Jbid.

Dworkin, supra note 77 at 31 .

Ibid. at 36 . 
testing the soundness of such a case - it is a matter of judgment, and reasonable men may disagree. $^{86}$

Thus it seems that the best interest of the child standard is not the all-powerful, ominous Khadi discretion critics fear. This discretionary standard allows flexibility to occur in a specific case where no hard and fast rules can be legislated to advance all the child's best interests. Judicial discretion is all about restraint speaking through the development of case law over time.

\section{F. THE BEST INTEREST STANDARD: A HISTORICAL REVIEW}

The literature on the best interest of the child standard is now to be considered from a historical perspective. Mintz notices transformations in family law in terms of the shifting balance among five broad themes of public discourse on the family: the changing functions of family law, everyone's responsibility (including that of the courts) for enforcing values, family law values, the form of legal intervention in the family, and changing family ideologies. ${ }^{87}$ Over time, the function of family law changed. In colonial times, family laws were taken from biblical teachings. Moral and religious themes abounded with a view to reinforcing communal norms. Here the function of family law was pedagogical.

By the 19th century, shifts occurred, in that family law became instrumental "as a way of resolving conflict, enforcing agreements, assigning rights and promoting socially desirable conduct. ${ }^{188}$

In the 20th century, Mintz finds also that the functions of family law again shifted, this time to secular and therapeutic themes. Courts now had the capacity to solve family problems. Since 1960 (perhaps because of the divorce revolution) expectations about what law can do have risen further. Law is now a social institution to effect social change. Mintz concludes there has been a gradual rejection of the idea that family law should be framed in moral terms such as fault or moral fitness. ${ }^{89}$ We seek not to blame when marriage breaks down; rather, we seek to restructure the family.

Mintz finds also that change in family law resulted, not just from changes in the legal system, but also from the economic transformation in society, together with a change in family ideology, function and gender relation. Essentially, the colonies were religious and patriarchal. Control by fathers, not only of the family production system but of land, skills, inheritance, children, and choice of marriage partner, was preeminent in the legal system. Patriarchal control slowly eroded as the family changed. The middle-class family lost its earlier character as the centre of production. The industrialization of society meant that father worked away from home, and as a consequence, middle class women gained new roles in the domestic domain and in 
child rearing. Gender and motherhood roles were at the heart of this redefinition. Children themselves were looked upon differently. They were seen as distinctive and unique - as individual persons. We often complain our custody laws are possessive in nature. The simple reality for families until the industrial revolution was that the need to guarantee a family's survival meant there was no period known as adolescence. Children were instruments of survival. They were sent off to work by their father for the betterment of the family, and hence, their father had possessory control over them. Economic shifts in the 19th century removed children from the workplace and sheltered them from the rigours of economic production. Once parents became aware of adolescence, they had to protect and supervise their children. ${ }^{90}$

By the 20th century, Mintz describes a radical shift in the economic position of women in the workforce which amplified the effects of change in the 19th century. Society placed new emphasis on children's rights. Mintz suggests this occurred, in part, because of growing litigiousness in society, where every group asserts its own set of rights. Divorce created growing stress on children through the erosion of the nuclear family. This resulted in a new phenomena, the single parent family.9"

In carrying out his analysis of these themes, Mintz concludes that:

Two elements stand out: a demoralization of family law, that is, a growing hesitance to discuss family issues in moral terms, and an erosion of explicit legal presumptions governing legal decision making, which has markedly broadened the reaches of judicial discretion. ${ }^{22}$

Like Mintz before her, Mason also tracked child custody and the best interests of children from a historical perspective. ${ }^{93}$ She concludes her history of child custody by questioning the purpose of child custody determinations. She answers that custody determinations are to advance the welfare of children and also believes that these same determinations should be about children. She is pessimistic about this because she took a historical account of the issue, not a normative one. She finds "that the legal history of child custody is far more about the rights of mothers, fathers, and masters rather than about the welfare of children." 94

In a critical review, Carbone finds Mason's conclusion unsatisfying because she did not articulate how the interests of children would lie if they could enlist adults in their service. In Carbone's view, Mason's historical approach, her preference for case by case decision-making, and her respect for children's relationships with adults who care for them, all clash with the approaches to custody now currently prevalent. Carbone

\footnotetext{
$9 \quad$ lbid. at 658-59.

$91 \quad$ Ibid. at 659.

$92 \quad$ Ibid. at 660 .

93 See generally M.A. Mason, From Fathers' Property to Childrens' Rights: The History of Child Custody in the United States (New York: Columbia University Press, 1994).

94. Ibid. at 188 .
} 
concludes that a missing ingredient in Mason's analysis is a vision of the family in which children are raised. ${ }^{95}$

Mason's account of modern custody litigation describes a time when our existing rules and assumptions were being undermined as legislatures, courts, and society searched to find a new set to replace the old ones. A framework about the kind of family life society desires is required whether designed by a best interests rationale, a joint custody preference or maternal deference concept. Mason suggests two major forces are at work, neither of which equates with the interests of children. We are concerned about defining the elements of parenthood. Society insists on responsibility for children. Familiar topics resonate here: deadbeat dads, child support reforms, and "fatherless America." ${ }^{16}$ Fathers' rights groups use conception-based responsibility to redefine father from bread winner to co-nurturer. From this perspective, fathers have a role to play in their children's lives independent of mothers. ${ }^{97}$

Some dispute this interchangeability of fathers and mothers and question the wisdom of the parental rights movement. Fineman is critical of the emphasis on formal equality of parents ${ }^{98}$ and "argues that 'family' should be defined in terms of the caretaking mothers have traditionally provided for children and other dependents." ${ }^{199}$ Fineman proposes the adoption of the primary caretaking standard as "children need day-to-day care, and the parent who provides that care should get custody." ${ }^{100}$ For Fineman, the starting point for family law policy is the "recognition of the mother/child dyad as the fundamental unit in its own right."101

This debate, permitted under the best interest of the child standard, introduces a familiar refrain found in the literature, a distrust about adults being counted on to represent children's interests. This includes the parents, children's advocates, and helping professionals, including mediators and experts. Because of this, Mason wished to entrust the courts with the ultimate decision-making power. A unified family court with appropriate support services figures prominently in her analysis.

Carbone takes a different view as she finds, from the history of family law reforms, a judicial distaste for family disputes. No fault divorce came into effect; hence judges were removed from the process of evaluating personal conduct. Judges became reluctant to reopen the parents' resolution of custody issues, much less to re-examine them, in the absence of complaint. Carbone notes that social science expertise and mediation had

J. Carbone, "Child Custody and The Best Interest of the Child - A Review of 'From Father's Property to Children's Rights: The History of Child Custody in the United States'" (1995) 29 F.L.Q. 721.

$\mathbf{6}$

D. Blenkenhorn, Fatherless America: Confronting Our Most Urgent Social Problem (New York: Basic Books, 1995).

Carbone, supra note 95 at 733.

\% See generally M.A. Fineman, The Neutered Mother, The Sexual Family, and Other 20th Century Tragedies (New York: Routledge, 1995).

99 Carbone, supra note 95 at 734.

100

101

Ibid.

Ibid. 
risen in acceptance, ${ }^{102}$ in large measure because of the expense and unsuitability of judicial resolution of these issues. The central theme of the critics is that, in the absence of clearly developed legal principles, judges have little expertise or inclination to decide whether the child would be better off "with attorney mom, prosecuting the trial-of-thecentury case in the middle of a divorce, or concerned dad, a dad who handled less of the child care during the marriage but had more manageable hours during the trial." ${ }^{103}$ She concludes; "[i]n an era of uncertainty, unguided discretion is an invitation to judges to act on their own ideals of family life." 104

Everything in the history Mason assembled suggests that the time is right for a full examination of the possibility of a child-centred family law jurisprudence. Mason favours judicial discretion as a solution because of trial courts' historic emphasis on case-by-case decision-making and their corresponding focus on the individual case at hand. Carbone points out that children's advocates do not all share this preference because a judicial ability to identify children's interests in custody cases has not been demonstrated, and there are pervasive problems of bias. She notes that "[f]eminists prefer a primary caretaker standard to a psychological parent one in large part because of their distrust of a judiciary dominated by old, white men and because of a corresponding preference for bright line rules." 105 This debate demonstrates how important it is to understand the effect that legal, social, cultural, or economic history has on the way society looks at children and family.

\section{G. CUSTODY APPLICATIONS IN THE PROVINCIAL COURT}

Custody applications in this Court are now reviewed from the perspective of what Pound called "law in action" ${ }^{106}$ as a prelude to the new model proposed in this article. Section 32 applications for custody define the parties as either parent or child. This creates two problematic issues: first, who is a parent, and second, how does a child apply when the application must be supported by affidavit? It is asserted here that "parent" now means "parental guardian." A biological father, who is not a guardian by operation of law, is a legal stranger and cannot invoke this section for relief until he has been recognized as a guardian.

This question of standing has been a matter of recent comment in this Court. With the decision of the Alberta Court of Appeal in H.A.D. and R.M.D. v. N.C.M, ${ }^{107}$ the law

Ibid. at 736; for a discussion on this movement, see M. Fineman, "Dominant Discourse, Professional Language, And Legal Change In Child Custody Decision Making" (1988) 101 Harv. L. Rev. 727.

lbid.

Ibid.

Ibid. at 737.

Dean Pound is sometimes called the founder of the sociological school of jurisprudence. Glueck described Pound's approach as being "neither sociology nor jurisprudence ... it is functional law - 'the law in action' and also 'the law in the books'; law relatively fixed, but also fluid, law influenced by history and disciplined by precedent, but also alert to the fact that history and precedent should not dominate the solution of the problems of an ever youthful society." $S$. Glueck, "Roscoe Pound and Criminal Justice" (1964) 10 Crime and Delinquency 299 at 347. H.A.D. and R.M.D. v. N.C.M. (1994), 145 A.R. 200 (Alta. C.A.). 
of Alberta is clear - only parental guardians have standing to apply. ${ }^{108}$ On this point, it is useful to revisit the best interests of the child standard. This standard has been used synonymously with parens patriae. These are correlated, not synonymous terms. If parens patriae is used as a synonym for the equitable power of a general jurisdiction judge, there is little difficulty. If it is used as something more than that, there is great difficulty because it means that a judge with this power can invoke it as a judicial override of specific statutory provisions. The latter use is incorrect. In C.V. v. J.L., I adopted Bushnell's reasoning and decided on a restrictive meaning for the phrase as meaning nothing more than judicial discretion. ${ }^{109}$ Provincial courts do not have inherent jurisdiction and do not operate in equity. The Court is bound by the statute and must not go beyond the four corners of its embracing jurisdiction. This Court cannot apply the law of equity to grant standing to third parties, such as grandparents, and thus broaden its jurisdiction.

It is not necessary that the applicant reside in the province of Alberta as there is no residency requirement set out in the statute. So long as the applicant attends in the jurisdiction through personal appearance, jurisdiction exists. The parents must be living apart, and there must be a legal dispute between the parties on the issues of custody and access. ${ }^{110}$

The applicant must complete an affidavit setting out material facts. Commensurate with the summary procedure approach in this Court, no great expertise is expected in pleadings. Nevertheless, when the Legislature invokes the words, "material facts," 111 it has in mind some specificity so that the responding party may understand what the applicant is seeking and why, and the court will have a like idea. At present, there are limited rules of practice in the Court, a consistent theme throughout the history of the justice of the peace system. When there are no rules, the Court is master of its own house and can create its own rules; otherwise the Alberta Rules of Court apply. ${ }^{112}$ In the thirty years the Court has had custody jurisdiction, it has never declared what applicants should tell the other parental guardian and the Court. Only one reported case suggests basic requirements. ${ }^{13}$ Once the applicant appears in person with a sworn affidavit, the Clerk then sets a hearing date, usually six to eight weeks away, so the applicant can serve the other parties.

For a chronology of relevant cases on jurisdiction for guardianship, custody and access in the Provincial Court see: White v. Barrett, [1973] 3 W.W.R. 293 (Alta. C.A.); $R$ v. Gingell, [1976] I W.W.R. 232 (S.C.C.); W.D. v. G.P. (1982), 54 A.R. 161 (Alta. C.A.); Re: L.G.A.B.G. (1989), 101 A.R. 92 (Alta. Prov. Ct.); Scott v. Hotchkiss (1990), 105 A.R. 354 (Alta. Prov. Ct.); Knight v. Knight (1992), 132 A.R. 341 (Alta. Prov. Ct); R.S. v. A.L. (1995), 158 A.R. 227 (Alta. Q.B.); R.B.F. v. K.G. (1993), 147 A.R. 376 (Alta. Prov. Ct.); H.A.D and R.M.D. v. N.C.M., ibid.; V.F. v. J.L. (1996), 163 A.R. 1 (Alta. Prov. Ct.); C.V. v. J.L., supra note 60. 
When the application comes to the docket court, the judge has a duty to comprehend what the case is all about, in a short time frame and in an extremely busy court. The judge's skill in dealing with people, grasping a sense of their problems, and giving directive orders is important; otherwise people may feel they get short shrift. Further, litigants in family matters feel uncomfortable standing before a judge, who is formally gowned, with a court room full of people quietly abuzz behind them. They must discuss questions about their personal family life in public. It is discomforting and disquieting for them.

Parents who cannot resolve their differences and agree to a consent order find the volume of business in the Court so great that no immediate court time is available for interim hearings. As a general pattern, one of two things occurs. The realities mean the judge makes no order until trial as the judge has scant information to make sense of the situation, let alone an appropriate order. Alternatively, the judge makes a series of short-term, consent interim orders to take care of any immediate crisis. The case then passes from docket list to docket list, from judge to judge. There is a substantial fall-off rate in that few cases go to trial. This should not surprise anyone interested in family law. ${ }^{114}$

One issue that directly affects the practice of this Court remains outstanding: what is the meaning of custody and access today in Alberta? ${ }^{115}$ Custody has an elastic meaning, as does guardianship. ${ }^{116}$ Guardianship is the most complete legal concept involving the parent-child relationship. Estey J., in Re B.C. Family Relations Act, expressed the point through a ladder rung metaphor: adoption (meaning rights obtained by an adult person through the adoption procedure in that the person then becomes a guardian) is the highest rung on the ladder of rights of an adult over a child, then custody, followed by access. ${ }^{117}$ Guardianship is not defined in the Domestic Relations Act, ${ }^{118}$ the Child Welfare Act, ${ }^{119}$ nor the Provincial Court Act. ${ }^{120}$ Generally a guardian has a duty to maintain, to protect, to educate, to provide religious education, to discipline the child - in sum, to socialize the child to grow up to become a socially appropriate, law abiding citizen.

In private custody law, the parental guardians are equal in status. What happens then when parental guardians separate? Does a custody order, by its very nature, take away the guardianship rights of the non-custodial parent? It is suggested that the answer has to be yes. If not, why do so many people launch custody applications upon separation?

Department of Justice, Canada, Custody and Access: Public Discussion Paper (Ottawa: Dept. of Justice, 1993) at 18.

This issue has been mooted in Alberta: see D. Cruickshank, "Guardianship and Custody Legislation in Alberta: A Review of Alberta Legislation" (Address to the Canadian Institute for Research and Law in the Family and Legal Education Society of Alberta, Banff Conference on Family Law, 1989) [unpublished].

Dept. of Justice, supra note 114 at 7.

Supra note 14 at 98 .

Supra note 56.

S.A. 1984 , c. C-8.1.

Supra note 10 . 
In this sense, "custody" and "guardianship" are synonymous. Indeed, support for this argument can be found in the Divorce Act which directs, notwithstanding a custody order, that the access parent shall be entitled to know certain things about the child's well-being. This traditional view is best expressed by Thorson J.A. in Kruger v. Kruger:

In my view, to award one parent exclusive custody of a child is to clothe that parent, for whatever period he or she is awarded the custody, with full parental control over and ultimate parental responsibility for, the care, upbringing and education of the child, generally to the exclusion of the right of the other parent to interfere in the decisions that are made in the exercising that control or in carrying out that responsibility. ${ }^{121}$

While this may be consistent with views from the 1970 s, ${ }^{122}$ it can be argued, based on the law and the relevant literature, that this is no longer a contemporary social value. Today, in making a custody and access order, some of one parent's guardianship rights are carved out in favour of the other parent. It does not follow that all of the other parent's guardianship rights are excised.

This issue came before the Supreme Court of Canada in Young and Droit de famille - 1150. ${ }^{123}$ In Young, McLachlin J. decided that custody orders do not extinguish entirely the access guardians' rights as they continue to have a right of participation in decision-making about their children after divorce. The differing views of L'HeureuxDubé J. in Droit de Famille would seem more commensurate with the opinion expressed by Thorson J.A. in Kruger.

The Supreme Court settled this debate in Gordon v. Goertz. McLachlin J., for the majority, decided that the visitation parent continued to hold residual guardianship rights. ${ }^{124}$ Therefore, such a parent continued to have a meaningful, ongoing role in the child's life. Such a parent ought to be consulted and involved in major decisions about the child. No longer was such a parent a mere visitor. This decision recognizes that a joint custody order may no longer be needed as a device to ensure that the access parent continued to have a role.

\section{H. CONCLUSION}

The jurisdiction of the summary procedure courts is no longer a "minor" or "small stakes branch" of the law. The issues the Court must deal with are of "first importance."125 Nothing can be more important than the welfare of children. How do they fare in this Court process? Generally, cases are the result of parental application.

Kruger v. Kruger (1979), 104 D.L.R. (3d) 481 at 485 (Ont. C.A.).

See generally J. Goldstein, A. Freud \& A.J. Solnit, Beyond the Best Interests of the Child (New York: The Free Press, 1973); J. Goldstein, A. Freud \& A.J. Solnit, Before the Best Interests of the Child (New York: The Free Press, 1979); J. Goldstein, A. Freud \& A.J. Solnit, In the Best Interests of the Child (New York: The Free Press, 1986).

Young, supra note 65 and Droit De Famille - /IS0 (1993), 49 R.F.L. (3d) 31 (S.C.C.).

See generally Gordon, supra note 65 .

Hurst, supra note 18 at 147. 
Children are in the hands of guardians who rarely understand what is expected of them in this Court, what information they must provide, or how they ought to approach resolution of their difficulty. Invariably, parents are lost in all but one respect. They always know what they want: an order from the judge in their favour. What do they encounter? They meet a judge invoking a standard often misunderstood and often applied under the pressures of time and volume. The child's interest may get lost or take a subsidiary role in the process.

The problem with family cases is largely case management. What is lacking in this Court is a sense of its identity, demonstrated by its lack of uniform procedures. This Court has the right to declare its own practice rules and create definitional certainty. If it does not exercise this authority, the existing system will continue. Currently, the Court does muddle through and, in all likelihood, because of the skill of the judges involved, does reasonably well. Judges engage in a continuing educational experience sitting in this Court through constant contact with psychologists, psychiatrists, and other mental health professionals, as well as probation officers. In consequence, judges offer something substantive to the community. What they do not do well is articulate a process which involves the people coming before the court, nor do they take charge of this process to make it efficient and beneficial for both the Court and the litigant.

This Court must be effectively reorganized and administered, basing its actions on established goals and applying recognized principles. In this way the Court can act with propriety and restraint:

A court cannot intervene in someone's life except in accord with legal processes. Above any institution of government, a court must itself demonstrate respect for law and not indulge in the hypocrisy of making the execution of the court's great power dependent upon the untrammelled authority of each judge $-\mathrm{a}$ trust that is placed in no individual by the law itself, nor should it be. ${ }^{126}$

To satisfy these concerns, this article proposes a new model of procedural justice to engage the interests noted here. The focus is on procedure in this Court because, as Thomas Jefferson said: "The execution of the laws is more important than making them."127

\section{A NEW MODEL OF JUDICIAL DECISION-MAKING}

\section{A. INTRODUCTION}

The behavioural and social sciences evaluate people's social experiences, relationships, and institutions based on outcomes. Thus, behaviours can be explained by outcome-based judgments. Lind and Tyler ${ }^{128}$ take a broader view, seeing people as more interested in issues of process than issues of outcome. This field of social 
psychology addresses how peoples' experiences and relationships are influenced by form. Lind and Tyler look at procedural justice: justice judgments based on norms of proper procedure. The term "procedural justice" is interchangeable with "procedural fairness." In Anglo-American societies, we employ the term faimess to describe "a social situation in which norms of entitlement or propriety are fulfilled." 129

The fairness of a given process and the outcome stemming from it are influenced by both objective and subjective standards. ${ }^{130}$ Part One of this article examined the objective backdrop to custody cases. Further objective restrictions exist through the operation of our laws of evidence and practice. Objective procedural justice is concerned with a court's ability to apply the laws of procedure and evidence as well as the rule of law; "to conform to normative standards of justice."131 For example, as this Court more closely approximates administrative tribunals, the Court must follow the rules of natural justice. The Court recognizes the audi alteram partem rule (hear the other side) which requires, on notice, a hearing in open court before the decision-maker with the right of cross-examination, appropriate evidence, and a right to counsel. The Court recognizes a second rule, nemo judex in sua causa debet esse (no man can be a judge in his own cause), commonly known as the rule against bias. The policy aspects relating to the rules of natural justice are well known. Justice must not only be done, but must manifestly and undoubtedly be seen to be done. ${ }^{132}$ Natural justice requires a tribunal, when engaged in reaching a decision, act with procedural fairness and stay within its jurisdictional boundaries.

In contrast, "subjective procedural justice concerns the capacity of each procedure to enhance the fairness judgments of those who encounter procedures." ${ }^{133}$ Fuller makes the fundamental point:

Adjudication is a social process of decision. This is true not only in the sense that it is a process of decision in which the affected party is afforded an institutionally guaranteed form of participation. It is also true in the sense that the success of adjudication, and the maintenance of its integrity, depend not only on the arbitrator, but on everyone connected with the process as a whole. ${ }^{134}$

There is a tension between subjective and objective procedural justice. Lind and Tyler employ two examples to underscore the point. In small claims court, people sense that they have an opportunity to tell their own story in their own way, taking as much time as they feel they need to articulate the issues that matter to them. This is their

Ibid. at 3.

R. Fisher \& S. Brown make this salient point: "In every situation we have two kinds of concerns: the way we handle the situation - process - and the results - substance. Process and substance are distinct but related; one affects the other." Getting Together: Building a Relationship That Gets to Yes (Boston: Houghton Mifflin, 1988) at 16.

Lind \& Tyler, supra note 128 at 3.

For a discussion of the principles of natural justice, the duty to be fair, and the rule against bias, see generally D.P. Jones \& A.S. de Villars, Principles of Administrative Law, 2nd ed. (Toronto: Carswell, 1994).

Lind \& Tyler, supra note 128 at 4.

Fuller, supra note 69 at 41 [emphasis in original]. 
subjective sense of the process. However, judges are limited by the exigencies of the system and must limit such opportunities for expression because they are concerned with efficiency and legal propriety. ${ }^{135}$ Judges have a duty to maximize objective justice and legal efficiency, which often oppose the desires of the litigant.

In the traffic court in Chicago, judges often believe that showing up for court and losing a day's pay is punishment enough for a traffic offence. ${ }^{136}$ The result for the people who attend court is that the judge dismisses their case without a hearing. This equates to a victory for them. There is no fine, no one goes to jail, and there is no record. Yet the research suggests general dissatisfaction from a personal perspective. While the outcome is highly satisfactory, the process is not. The litigants never have a chance to explain their particular point of view or tell their story. The litigant, in this process, is not subjectively understood.

Research on procedural justice recognizes that by judicious choice and design of procedures, a court can enhance not only the quality of the relationship of the litigants, ${ }^{137}$ but also enhance the satisfaction with the judgment, no matter what that judgment says. Routes to satisfaction depend on more than favourable outcomes.

Lind and Tyler's conclusions can be summarized: ${ }^{138}$ procedural justice effects are robust across methodologies; in most situations, procedural justice judgments lead to enhanced satisfaction; this effect is especially strong when outcomes are negative. Procedural justice is an important factor in deciding which procedure will be preferred by those affected by a decision; procedures are viewed as fairer when they vest process control or voice to those affected by a decision; judgments of procedural justice enhance the evaluation of authorities and institutions; procedural justice affects behaviours, as well as attitudes and beliefs, and procedural justice processes operate in arenas other than courtrooms. Also, procedural justice involves more than questions of how decisions are made, it involves questions of how people are treated by authorities and other parties. Process control effects are based on more than a desire for fair outcomes. The opportunity to express one's views by itself enhances procedural justice judgments. Judgments of procedural justice involve more than control issues. Procedural justice is affected by other formal characteristics of procedures, and by nuances of interpersonal behaviour.

Part One of this article detailed the Court's existing process model for custody cases. It is the Court's experience that cases often get adjourned from time to time, from docket court to docket court, with a series of consent orders taking care of any immediate crisis. Delay allows the parents an opportunity to work through their

Lind \& Tyler, supra note 128 at 5.

For a similar finding in a criminal court (the court of common pleas in Connecticut) see $M$. Feeley, The Process is the Punishment (New York: Russell Sage Foundation, 1979).

"[T]he outcome of a particular transaction depends not only on our negotiation skills. It also depends on our relationship with those with whom we are negotiating" (Fisher \& Brown, supra note 130 at xiii).

Lind \& Tyler, supra note 128 at 206-16. 
difficulties. All court appearances are brief. Evidence is not usually heard, or required. ${ }^{139}$ It is not uncommon to have a series of ongoing, interim orders without any final resolution.

The proposed three-stage model improves on the existing process. In the first or application stage, the Court adopts a standardized affidavit that both parties must complete, not just the applicant, so that the Court obtains a base of information about the parents and the child. ${ }^{140}$ Acting on the principle that guardians have a duty to advance their children's best interests, the Court compels parents to give the Court sufficient information to make reasoned decisions. In the second stage, the judicial dispute resolution stage, the Court affirms two basic concerns of procedural justice: first, the need for normative standards to be applied for reasons of efficiency and legal objectivity, and second, the need for the parties to participate fully in the process to answer the concerns of subjective procedural justice. Stage two effects a neat balance between the right of guardians to private ordering and the inherent checks afforded by public ordering of a court system. This stage invites the judge to actively adopt the role of mediator. If no success is achieved the judge can offer a mini-trial ${ }^{141}$ hearing to the parties and render a non-binding, judicial expression of opinion with a view to settlement before the parties get a confirmed trial date. ${ }^{142}$ The role of the judge is important, as the judge employs all his or her knowledge and experience to help the parties reach a wise solution without the necessity of trial adjudication. ${ }^{143}$ The judge will use mediation skills to work with the parents, in open court, on the record, without hearing evidence, in an attempt to resolve the difficulties. This may be done over time through a series of consent orders and adjournments, provided the case moves towards disposition. If the judge does not succeed at this stage, the judge continues the process by turning to the mini-trial. The Court requires the parties complete parenting plans at this point, with the judge then giving an assessment of the case. Thus, the parties receive an independent, non-binding expression of judicial opinion based on the best

For a similar practice in California, see Stevenot v. Stevenot, 154 Cal.App. 3d 1051 (1984).

Failing this, judicial passivity will lead to the result noted by Bayda J.A. dissenting in Wakuluk v. Wakuluk (1976), 25 R.F.L. 292 (Sask. C.A.): "No one bothered to bring forward much information in respect of the two individuals who of all the persons likely to be affected by these proceedings least deserved to be ignored - the children. We know their names, sex and ages but little else.... In short, no evidence was led to establish the intellectual, moral, emotional and physical needs of each child.... Nor was any direct evidence led to show which of the parents ... is best equipped to meet the needs of each individual child" (at 299-300).

This model is the creation of The Honourable Chief Justice W. K. Moore and has as its key elements: (1) All counsel must agree to participate; (2) The clients must be present; (3) Counsel present their arguments to the judge who then renders a non-binding opinion; (4) There are no costs; (5) No evidence is introduced - only arguments based on agreed on facts; (6) Counsel and the judge caucus before the mini trial to set the procedure, and (7) The mini trial judge will not be the trial judge. See "Mini Trials Reduce Clients' Stress and Expense" (1992) 27 Benchers Advisory 11 and W.K. Moore, "Mini-Trials in Alberta" (1995) 34 Alta. L. Rev. 194.

Research in the community mediation field indicates that mediation/arbitration models are more effective and produce different client and mediator behaviours than do straight mediation or arbitration models. See D.G. Pruitt, "Process and Outcome in Community Mediation" (1995) 11 Negotiation Journal 365.

A similar approach has been suggested in the United Kingdom. See Judge Hyam, "Changing the Style of Advocacy" (1996) 26 Fam. Law 406. 
interest standard from a judge who has acquired knowledge about them and the child after their full participation in an informal manner. Should the parties continue to disagree, the Court now moves to the third stage, the trial. The Court gives the litigants a confirmed trial date, before a new judge. Trials proceed in the usual way. This is a judge-made guideline approach based on current community values about children that the Court or the parties can alter as circumstances demand. Flexibility is the key.

Society today must be concerned about the ever-increasing volume of custody disputes filed in the courts. Society may change this pattern by substantive law amendment, yet the Alberta Legislature shows no enthusiasm for such a proposal. A second way is to explore alternatives to court resolution. In today's court system both courts and litigants seem to want alternate techniques to aid them in their tasks. Few cases ever reach trial: they are resolved in some fashion along the way. This Court, with little statutory procedure in its history, is ideally suited to adopt new methodologies to resolve family disputes. Some call this case management; some call this pre-trial conferencing; some call this case conferencing. Courts are now moving away from idealized notions of the adversarial model of dispute resolution. The task facing those who participate in the court system is to understand which cases must be left for the courtroom and which can be dealt with in another way. ${ }^{144}$

An understanding of other methods of dispute resolution is helpful. Sander classifies various methods of dispute resolution along a spectrum of decreasing external involvement of third parties. ${ }^{145}$ Sander sees the processes of dispute resolution as a continuum commencing with negotiation through mediation, conciliation, ombudsman or fact finding inquiry, followed by adjudication, be it by a court, arbitration, or administrative process.

Self-regulation is the most informal and unstructured of the dispute resolution systems, while the adversarial model is the most formalized with the other processes lying somewhere between. If parents are to make a wise and prudent settlement in custody disputes, one common feature must prevail in all dispute resolution mechanisms: knowledge of the context, knowledge of the subject matter, and knowledge of the persons involved. Knowledge is power. With knowledge, facts are agreed to, which then become potent tools for inducing resolution between the parties.

Kaye J. of the New York Circuit Court of Appeals notes: "As a society we seem to have developed a mind caste that the courts should resolve every crisis in our lives, and the escalating ... court filings show there is no relief in sight... We all recognize that cases are more than numbers and statistics. They represent flesh and blood controversies often profoundly affecting people's lives. Moreover, court judgments throughout history have shaped and defined matters of great societal significance.... However, there are still hard realities about the litigation process today that cannot be ignored ... many cases in the courts-particularly those involving disintegrated personal relationships-probably do not belong there at all; indeed, keeping such disputes in a formal litigation mould may often times actually exacerbate the human tragedy... Therefore, it is essential that we find those cases and non-cases that are needlessly distorting and misshaping our adversary system and resolve them in other ways." J.S. Kaye, "View From The Bench" (Summer 1987) Dispute Resolution 17 at 17.

F.E.A. Sander, "Varieties of Dispute Processing" in Tomasic \& Feeley, supra note 25 at 27-30. 
Sander notes that dispute resolution mechanisms have other important features besides resolving the dispute. First, there is a therapeutic value in letting people have their say, while other people must listen. Second, when there is an ongoing relationship in existence, dispute-mechanism systems have a pedagogical effect in teaching the litigants how to restructure their relationships to avoid future conflicts.

\section{B. STAGE ONE: THE APPLICATION}

In the analysis of this Court in Part One of this article, it was maintained that the essential model of the Court is a conciliatory one, not an adversarial one. It follows then that the Court can structure this process so that litigants feel comfortable with a degree of informality, yet there is some understood structure that assures their full participation. This proposed model of dispute resolution should be a synthesis of various dispute methodologies encapsulated into a court system. This latter point remains central since the judge must still effectively protect the rights of the parties who may be disadvantaged, including, in custody cases, the child.

In the application stage, the Act requires the applicant to appear in person and file an affidavit setting out material facts before receiving a hearing date. If the respondent party wishes to appear and be heard, there are good reasons to hear that person's story in an affidavit as well: the dispute can be readily defined and understood. The Act does not specify or direct the contents of the affidavit. What does the Court require? It is the duty and responsibility of guardians to advance and protect the best interests of the child. The affidavit is the first opportunity the Court has to focus parents on this task. The Court must demonstrate, through the form of affidavit, a shift in focus from parental rights to a child-centred perspective.

While thoroughness is an admirable quality, nevertheless the affidavit must be easily understood and completed. In person litigants often do not have ready access to legal assistance. Retaining lawyers is often beyond their financial means. Legal aid is not usually available. Some litigants have language difficulties. Others have a wrongheaded sense of what the law is in the custody area. Everyone recognizes the emotional turmoil of separation and divorce: it is never the best of times for parents or children. Thus, the Court should format the affidavit to enable parents to tell their story easily.

Finally, the affidavit entitles the Court, under the guise of a practice rule, to set out, in a preliminary way, its collective sense of community values about children. Affidavits should be viewed as precursors to what will happen in the next stage of the proceedings. Its emphasis has to be on parenting for the child. The affidavit should recognize that only the marriage is ending, not the parent-child relationship.

The Court has the right to detailed, accurate information. No longer can parents hold courts hostage for their private whims and wishes, for such actions are not childcentred. The judge has the statutory right to compel evidence. ${ }^{146}$ Parental guardians must accept this legal reality. If they choose to use the Court system, they must 
understand the role of the judge in the process. Parental bargains do not bind the Court. The Court must act independently of the parents, and in so doing, the Court protects the interests of the child. Should the parents feel displeased with this legal and social reality, the law allows them to arrange their own contractual bargains outside the purview of the Court.

Basic community values come to the fore at the application stage. Child time must never be withheld from a parent, absent compelling reason: "Maximize the contact with parents and minimize the conflict." ${ }^{147}$ Family violence is no longer acceptable in society. No court will grant a judicial seal of approval in this realm. If there is one central understanding we have of children's issues it is this: children do not thrive on conflict; quite the opposite, they inevitably suffer harm from it. Courts must stop conflict, especially abuse. Judges require disclosure in the affidavits of past acts of violence; past abuse will influence the court's approach to dispute resolution. Many doubt the appropriateness, let alone the effectiveness, of mediation in cases of violence. ${ }^{148}$

Affidavits need to provide detail about who the parents are, where they live, what they do, the time they have for parenting, and how they have parented in the past. Capacity, motivation, and opportunity are important considerations. Is there anything relevant in the family's history that society defines as a parenting disability or deficiency such as a history of alcohol or drug addiction, parental abuse, and severe emotional disturbance? The Court needs to know something about the family's past arrangements when the family was intact. It is important to gain a sense of the family before the breakup. Who did the parenting? Who provided for the child's needs? What were the attachments to the child? Who consistently made and applied the rules in the household?

The affidavit should also tell the Court something about the child as an individual and about the child's environment. Is daycare involved? Who are the babysitters? If so, why are they involved when there is a parent available? Is the child in school? What is the experience of this child in school? Are there problems at school? If so, what materiality do they have to the separation and this proceeding? What health, emotional or developmental difficulties exist, if any? Is the child seeing a doctor, counsellor or therapist? If so, is there any connection between professional care and the separation, or does the need for professional care have something to do with the family history

147 A. Charlow, "Awarding Custody: The Best Interests of the Child and Other Fictions" (1987) 5 Yale L. \& Pol'y Rev. 267 at 281.

148 Like all generalizations, this is an oversimplification. Research into typologies of violence in highconflict marriages and divorces aids in the understanding of whether mediation should take place at all. See J. Johnson \& L. Campbell, "A Clinical Typology of Interparental Violence In DisputedCustody Divorces" (1993) 63 Am. J. of Orthopsychiatry 190. A more discriminatory approach is warranted as, under certain conditions, mediation may be more beneficial than detrimental, as domestic violence is not uni-dimensional or uni-directional. See J.B. Kelly, "A Decade of Divorce Mediation Research: Some Answers and Questions" (1996) 34 Family and Conciliation Courts Rev. 373. 
before the marital breakup? Generally, how is this child functioning in his or her home, neighbourhood and school?

From the presenting affidavits, the Court can quickly glean a sense of positive and negative. While in an individual case there can be appropriate additions or deletions, the affidavits begin a structured process for decision-making by bringing together objective and subjective procedural justice elements.

\section{STAGE TWO: JUDICIAL DISPUTE RESOLUTION}

\section{Case Management}

While it may be the case that the Court exists to bring justice to every person's door, it does not follow that every family dispute requires a trial. A fundamental premise operating in court systems is that a court is responsible for supervising the progress of each case from filing to disposition. The goal is to make the sequence of events in a court action both predictable and timely. Case management increases the probability of an early and fair disposition of the case. ${ }^{149}$

The Court can make accommodations to allow parents greater participation in this process. This article proposes a case management model to effect subjective procedural justice and meld it with the Court's own notion of the normative standards employed in child-centred custody decision-making. If the Court successfully manages this fusion, public confidence in the Court will be enhanced. Litigation satisfaction will increase. Better judgments invariably will follow.

The American Bar Association has created case-management standards:

(1) From the commencement of litigation to its resolution, any elapsed time other than required for pleadings, discovery and court events, is unacceptable and should be eliminated.

(2) To enable just and efficient resolution of cases, the court, not the lawyers or litigants, should control the pace of litigation.

(3) A strong judicial commitment is essential to reduce delay and then maintain a current docket. ${ }^{150}$

It follows from this general statement that the case no longer belongs to the lawyers or to the litigants. The underpinnings of case management include these axioms: early and continuous court control of case progress avoids or reduces backlogs; dispositions occur when decision-makers have the necessary information; every case, without exception, must always have assigned a date certain for a purpose certain; date certainty disposes of cases; achieving dispositions before trial dates are set conserves time and 
resources; a judge with open time disposes of more cases than one constantly in trial; and accurate, timely information is essential.

A case management model is a goal-orientated process that structures a predictable, regulated flow for each case from filing to disposition. The Court must pay attention to each case from its earliest point of entry in the system and monitor it. The Court can differentiate its caseload: some cases are of a standard type, showing no emergent characteristics and no undue complexities; some cases demand, by the nature of issues involving a child, an immediate hearing; others are complex and must be given special attention within a high volume, summary procedure court. Because the Court controls its process, trial dates should not be given except by order of the Court, and only when the case is ready for trial and cannot be disposed of in any other reasonable fashion. A trial date must be a credible date. The parties must understand that adjournments are not the norm; they are the exception. Trials go on at the time specified.

This proposed model includes this case management strategy employed through the use of mediation and mini-trial techniques. Family mediation, following the standards of practise of the Academy of Family Mediators, is based on principles of problem solving "that focus on the needs and interests of the participants; fairness; privacy; selfdetermination; and the best interests of all family members." ${ }^{\mid S 1}$ Mediation, in familycentred conflict resolution, is understood to be a process in which an independent, impartial third person helps the participants resolve their dispute through an informed settlement. The agreement is structured in a way that helps maintain the continuing relationships of the people involved. Decision-making authority rests with the parties. The role of the mediator includes reducing obstacles to communication, maximizing the exploration of alternatives, and addressing the needs of those involved, especially the unrepresented child.

It is useful to distinguish mediation from arbitration. Fuller explains the different purposes and morality of mediation and arbitration. The point of mediation is to achieve an "optimum settlement - a settlement in which each party gives up what he values less in return for what he values more." ${ }^{152}$ Arbitration's purpose is to form a decision according to the submission which contractually prescribes the duties of the arbitrator. The procedures used for mediation are those that are most likely to uncover a pattern or process of adjustment which will most nearly meet the interests of the parties. Arbitration more closely resembles a court adjudication system because the parties are guaranteed participation through factual presentation and arguments. The differences between mediation and arbitration can be best understood, in Fuller's view, with respect to the fact finding processes. In mediation, there is no essential fact finding as this is understood in an adjudication context. Essential facts are facts the parties themselves decide are important. Such facts may or may not exist according to any objective standard. In relative terms, fact finding in mediation is of less importance than the 
ultimate settlement. An arbitrator takes a different view of the facts because the arbitrator is the fact finder, not the parties themselves.

When mediation does not achieve a satisfactory settlement, the judge can continue the judicial dispute resolution process by conducting a mini-trial. The mini-trial model is an effective way of telling the parties who have failed to resolve their dispute over custody what a judge has to say about this dispute. The parents exchange information and discuss the issue in open court. The judge benefits from the parents' input in the process, thereby fulfilling the subjective procedural justice requirement. The judge then invokes normative standards that exist in the community to satisfy objective procedural justice standards. This part of the process is non-binding and without prejudice as it is covered under the rubric of litigation privilege. Informality exists allowing full participation of the parties. No evidence is heard. The process is weighted towards private resolution of the dispute in a prudent and timely fashion.

The role of the judge in this mediation process is more interventionist than in the traditional adjudication system. The justice of the peace is the genesis of this court. The justice of the peace was chosen to deal with community issues, because of his position in the community and ability. Such a person was close to the community, had the confidence of the state, and was capable of bringing a sense of fairness to bear on local issues. The judge in the summary procedure court has a similar role. To forestall any suggestions of arbitrariness and to ensure fair dealings, the judge carries on this process in open court. Open hearings afford appropriate protection from any later suggestion of impropriety or undue influence, should there be an attempt to collaterally attack the process.

\section{Negotiation and Mediation}

Negotiation and mediation is, simply put, a basic means of getting what you want from others. Most people reach decisions through negotiation without having to go to court. Mediation can be likened to a structured negotiation or cooperative negotiation. The point of mediation is to negotiate, not just any agreement, but a wise agreement. Such an agreement is one reached in an efficient way. A negotiated agreement resulting from co-operative negotiation at best improves, or at worst does not occasion damage to, the relationship of the parties. Finally, the negotiated agreement should survive the test of time.

When people negotiate, they must resolve two potentially conflicting objectives: short term personal gain with long term relationship maintenance. This has been called the "bargainer's dilemma." ${ }^{153}$ The bargainer's dilemma can be shortly stated: if one party negotiates aggressively to reach an agreement favourable to his interests, it is conceivable that this person will gain more. However, at best, such a person runs the risk of disrupting the relationship or, at worst, securing no agreement at all. Fuller raises this in his commentary about exchange theory. He quotes Barnard: 
The rule must be that you give, so far as possible, what is less valuable to you but more valuable to the receiver; and you receive what is more valuable to you and less valuable to the giver. This is common sense, good business sense, good social sense, good technology, and is the enduring basis of amicable and constructive relations of any kind. This does not mean that you give as little as you can from the receiver's point of view.... What conceals this simple fact of experience so often is that subsequent evaluations may change, though this is then beside the point. I may pay a man $\$ 10$ today with pleasure, and find tomorrow that I need $\$ 10$ very badly, but cannot use the services I paid for. I am then perhaps disposed to think I made a bad exchange. I read the past into the present. This leads to the false view that what exchange should be is as little as possible of what the receiver wants, regardless of its value to me. This philosophy of giving as little as possible and getting as much as possible in the other man's values is the root of bad customer relations, bad labor relations, bad credit relations, bad supply relations, bad technology. The possible margins of co-operative success are too limited to survive the destruction of incentives which this philosophy implies. ${ }^{154}$

Emery makes the distinction clear by his description, from game theory, of two basic approaches: the competitive approach, sometimes known as zero sum bargaining or distributive bargaining, and the co-operative approach, often known as positive sum disputes or integrative bargaining. ${ }^{\text {iss }}$ Zero sum bargaining is used in everyday financial negotiations. Think of the ordinary house sale. Each party's interests are in direct opposition to one another. This can be represented as a zero sum dispute which is a win or lose proposition. The more one side wins, the more the other side loses. The sum of the loss on one side and the gain on the other adds up to zero. The primary focus of a competitive, zero sum negotiation, is to resolve distribution, i.e., how to divide whatever is being disputed. As each side begins by making an initial offer that is presented to the opposite party as an acceptable resolution of the dispute, it encourages position as opposed to interest bargaining. Zero sum or distributive bargaining tactics include intransigence, secretiveness, extreme positioning, and patience. Distributive bargaining is an imperfect method of resolving a custody dispute as it is hard to rationalize the attributes expected of distributive bargaining being in a child's best interest.

Co-operative or positive sum dispute resolution systems, such as mediation, have, as their underpinning, a different assumption than the competitive, zero sum type approach to negotiation. In the co-operative model, the parties to the dispute recognize they benefit through co-operation even though there may be difficulties between the two. Co-operative dispute resolution systems work best where there are ongoing relationships such as we have in family matters and custody disputes. Resolution through cooperation has a direct bearing on the continuing relationship. In theory, a positive sum dispute is one in which there does not need to be a winner and a loser. ${ }^{156} \mathrm{~A}$ compromise solution reached in such a bargaining process is one where the total benefit reached exceeds the joint benefit of one-sided solutions, thus the term, positive sum.

C. Barnard, The Functions of the Executive (Cambridge: Harvard University Press, 1954) at 25455.

R.E. Emery, Renegotiating Family Relationships: Divorce, Child Custody and Mediation (New York: Guildford Press, 1994) at 96-100.

Ibid. at 99. 
This kind of integrative bargaining is particularly useful when the values of the parties differ. Each party is entitled to put a value on what it desires. The other party may not accept the same value; therefore co-operation allows benefits to accrue to each side without any objective decision about value being necessary.

Procedural co-operation requires good faith communication between parties who are mistrustful of each other. In child custody disputes, co-operation involves compromise by the parents for the joint good of their child. The mediator must use the mediation process to gain the trust of the parties, open the lines of communication, contain the emotions that affect the dispute and work towards a solution. It is frequently the case that a mediator perceives an overlap in the parties' respective positions, especially today when parents should accept a child-centred approach to their dispute resolution. Several important considerations are connected to bargaining involving children which parents must understand. The child is a developing person; children develop in well understood ways; children must be permitted to reach their developmental milestones; if they fail to do so, there can be negative ramifications which are well known and understood. Parental conflict does not enhance the developmental process; indeed, parental conflict can cause great harm. Parents, through mediation, must move some distance from the immediacy of the moment and the emotionalism it entails for the good of their child.

One of the benefits of mediation or the cooperative negotiation process compared to the competitive approach is the parties' ability to achieve results in time. One of the assumptions competitive negotiation makes is that one side will not co-operate, and that nothing of value will be gained from co-operation. For in person litigants, time is a luxury they do not have. Often forgotten are the inherent limitations people have in society as they struggle to meet the exigencies of everyday living, together with the demands of their workplace. Parents rarely have the time to sit on the courtroom bench, waiting for their turn in docket court. After removing the issue of dollar costs from the competitive bargaining model, one of the greatest difficulties facing litigants using that model is its time-consumptive quality. One side will never be in a hurry to conclude the dispute, unless there is a favourable gain to that side.

In person litigants recognize they have difficulty with custody disputes; they need the Court's help, and want to have an expeditious hearing. The Court also desires timely results, because of limited resources. Further, separation and divorce are now part of our social fabric, accepted by parents as social realities, no longer stigmatized. People are resilient and must get on with their lives. In person litigants want, above all else, guidance and assistance from the Court. They come to this Court by choice. They need help now. Co-operative bargaining with an impartial, independent judge to guide them is preferred. The system should accommodate their wishes. The role of the judge always will be that of a neutral person, armed with special knowledge and training, and skilled in dispute resolution mechanisms. The judge is a catalyst for settlement of private interests, and a guarantor of the interests of the child.

A single judge will mediate a given custody dispute up to, but not including, the trial. If the parties are unable to resolve their dispute through mediation, they will at least have understood what the Court thinks is important, they will understand the kind 
of information they require, and they will have enhanced the prospect of an efficient, fair trial.

\section{Separation and Divorce}

There are several models conceptualizing the divorce process, which is no longer thought of as a single event. Wallerstein emphasized the psychological task of divorce. ${ }^{157}$ Others emphasized the various social, psychological, legal, and economic components of divorce. ${ }^{158}$

The separation and divorce process is well studied. Maccoby and Mnookin discuss the consequences of separation and divorce for parents and children. ${ }^{159}$ They see four kinds of divorce occurring after separation involving children: (1) spousal (the end of intimacy); (2) economic (the redistribution of wealth/debt); (3) parental (the new parenting regime); and (4) legal (the setting down on paper of the result of the event of separation and divorce). ${ }^{160}$ Neither Maccoby nor Mnookin assume that these four stages go in a calm, regulated, chronological order. Similarly, Ricci describes four kinds of divorce: the legal one, the one from intimate love, the one from anger and hurt, and the one from competition. ${ }^{161}$ Weitzman and Adair recognize at least three stages in the process of divorce: the acute stage, the transitional stage and the post-divorce stage. ${ }^{162}$ In the acute stage, they see the period of maximum conflict and disruption for children and adults. The adults must now cope with the demands of living apart and establishing an independent social life. While they are undergoing this transformation, their children have to deal with the lack of physical and emotional connection between the parents; they often do this through denial. The transitional stage follows and generally lasts from one to two years. After the immediate crisis is handled, new social and economic realities have to be faced and are continuing stressors. The Court is usually engaged at this stage and must deal with conflict in areas of parenting, child support, visitation, spousal support, and property matters. Children are involved because they see and hear conflict. Sometimes they become allies or go-betweens in their parents' dispute. Eventually, the post-divorce stage is reached. Parents must make new lives for themselves after putting their houses in order. Some habitually conflicted couples stay enmeshed and never resolve their conflict because of an unconscious need of at least one member of the couple to stay involved. The children are caught in a life of uncertainty and ambivalence. A final factor which usually adds to the conflict or confusion is remarriage or a new relationship. All factors are prominent stressors in a child's life.

J.S. Wallerstein, "Children of Divorce: The Psychological Tasks of the Child" (1983) 53 Am. J. of Orthopsychiatry 230.

Emery, supra note 155 at 18.

See generally E.E. Maccoby \& R.H. Mnookin, Dividing the Child: Social and Legal Dilemmas of Custody (Cambridge: Harvard University Press, 1992).

Ibid. at 19.

I. Ricci, Mom's House, Dad's House: Making Shared Custody Work (New York: Macmillan, 1980) at 16.

M. Weitzman \& R. Adair, "Divorce and Children" (1988) 35 The Paediatric Clinics of North America 1313 at $1315-16$. 
Haynes connects the divorce and mediation processes. ${ }^{163}$ He sees the stages of the divorce process as marriage ending, deliberation, announcement, acceptance of decision, mourning, transition, and redirection. The mediation process best tracks this process, commencing with announcement and separation as mediation works best when there is a degree of acceptance by the parties of their marriage breakdown and the tasks now facing them.

It is an understatement to say that separation and divorce for adults is difficult because of stress, emotional pain, financial challenges, and the uncertainty of an unknown future. It is important to understand the reactions of adults to divorce. Many parents cannot solve their custody disputes because they cannot solve their own individual or interpersonal conflicts brought about by their separation and divorce.

Reactions to divorce are often demonstrated in parental behaviour before a judge. Bowlby ${ }^{164}$ sees the experience of grief involving four stages: numbing, yearning and protest, disorganization and despair, and reorganization and attachment. Bowlby recognizes that both children and adults are initially numbed by a loss; they then try to reunite through angry protest. Failing this, they fall into a confused and sometimes depressed state. Finally, they resolve the despair by becoming detached. The special bond between them and the former attachment figure is lost, and they move on alone. While the reasoning of Bowlby may be relevant, a difficulty exists. Distress felt on divorce, while like the grief experience following the death of a loved one, has a distinguishing feature. Nothing is ever final in divorce, viz. the children. Perhaps no single factor has greater significance. Children are a constant reminder of the marriage.

Ricci's divorce scenario is especially helpful to judges rendering custody disputes. ${ }^{165}$ Ricci deals with the emotional impact of divorce and breaks it into five components. Her first stage, which is the pre-separation stage, shows the main emotion to be denial, followed by an erosion of mutual trust and respect. The separation stage, stage two, demonstrates the emotion of shock, coupled with relief. Stage three, which she called the strong emotion stage, or, in her colloquial term, the "off the wall" stage, demonstrates a time of sudden and intense emotional reactions. The mother and father seen at this time are not the mother and father one would normally expect. Mother and father can be out of control at this stage. At stage four, the stage she called adult adolescence, parents demonstrate a realization that the benefits of marriage are gone and adopt an adolescent stance demonstrated by a new excitement for life, new sexual urges, and a preoccupation with self and new friends. In the final stage, the stage of new maturity, parents develop a new sense of self and become happy with new personal roles and relationships. They are now uncoupled.

The importance of this knowledge to the Court should be clear. The in person litigant undergoing this process may demonstrate some or all of the behavioral patterns outlined by Ricci. The judge, acting as mediator, should not over-interpret what is being said 
while allowing litigants to speak about their experiences; there is a therapeutic value to mediation. Mediation is not always prospective. The mediator must recognize that people's feelings are real and common. Yet people have to move on. They must understand the impact their behaviours have on children. We recognize intuitively that the best interest of a child is intimately intertwined with the physical and emotional well-being of parents and new family units. A parent who is comfortable with self and has moved through the process of divorce to find a self in a new environment should parent more effectively than one who is under considerable stress, unhappy, confused, and uncertain about his or her future. Parents have to make themselves well to be effective parents; otherwise there is a danger that their children's development will be at risk. Hence, it is important to have some understanding of basic child development and the impact and reactions of children to the parental separation and divorce. ${ }^{166}$ While it is beyond the scope of this article to deal extensively with child development, and this has been done elsewhere, ${ }^{167}$ an overview is useful for decision-makers.

\section{Child Development Issues}

Child development may be defined as the study of maturation and change in body structure and functions from conception through fetal life, culminating in adolescence. ${ }^{168}$ In this process, nature and nurture work interactively to promote, or in some case prohibit, development. Therefore, any assessment of a child, with this definition in mind, must consider numerous factors, among them the child's environment, the family's genetic background, and the child's individual level of development. The critical issue is whether a child has successfully completed the resolution of the central issue of his or her maturational milestone, be it motor control, language acquisition, or social and cognitive skills. The children who do not meet development milestones will be left developmentally arrested or handicapped for future development. An issue for judges is whether this difficulty arises because of the parents' separation and divorce or because of some other factor. The judge should not assume that the difficulties demonstrated by a child are anything more than situational. Nevertheless, a difficulty evident at the time of separation may be much more than what it appears to be, and judges should be involved in canvassing this issue.

See generally H.F. Landerkin \& M. Clarke, "Divorce Effects on Families: Helping Strategies for Primary Care Physicians" (Paper presented to the 35th Scientific Assembly, College of Family Physicians, Alberta Chapter, Banff, Alberta, 1 March 1990) [unpublished].

See J. Edwards, Child Development: A Judges Reference Guide (Reno, Nev.: National Council of Juvenile and Family Court Judges, 1993); Resa Garon et al., Guidelines for Child Focused Decision Making: A Manual for Judges, Attorneys, Mediators, Mental Health Professionals and Parents Concerning Child of Divorce (Columbia, Md.: The Children of Separation and Divorce Center, 1993); N. Kalter, Growing Up With Divorce: Helping Your Child Avoid Immediate and Later Emotional Problems (New York: The Free Press, 1990); W.F. Hodges, Interventions For Children of Divorce: Custody, Access and Psychotherapy, 2d ed. (Toronto: John Wiley, 1986); S.D. Dixon \& M.T. Stein, Encounters With Children: Paediatric Behaviour and Development, 2d ed. (St. Louis: Mosby Yearbook, 1992).

See generally Edwards, ibid. 
The first three years of life are crucial to successful development. Children need a secure base on which to build. ${ }^{169}$ During the first period of child development, from birth to eighteen months, bonding and the development of trust are critical. One of the central social skills that humans must develop in this period is the ability to trust other people. Often used interchangeably, "bonding" and "attachment" are different terms. ${ }^{170}$ "Bonding" refers to the parents' initial experience of attachment to the infant. "Attachment" is the term generally used to describe the infant's experience of belonging with another, an experience essential to healthy human development. Therefore, the first psychological and social task in life for the infant is to become attached to his or her parents or other caregiver. Bonding flows from the parent to the child while attachment works in the reverse. ${ }^{171}$ What the infant needs is a secure foundation for trust with all that entails: a nurturing environment including the essential elements of food and shelter together with the holding, stroking, cooing, and mutual play that make up healthy physical and emotional stimulation. These attachments and bonds are formed by the quantity of time spent and quality of caretaking provided.

Children in this stage are almost totally dependent on their caregivers and require a great deal of time, attention, and patience. It follows that the child's first important connection will be with the person who provides the most regular and stable child care. The key factors to evaluate this relationship are caring, consistency, and time. ${ }^{172}$ Too many changes for the child interfere with the child's development as they have an impact on the child's sense of trust. A child needs predictable routines. Conflict between parents is something a child can not understand. A child recognizes the tension of fighting as this is not a predictable routine. Such a child reacts by showing nervousness, becoming fussy, and with continuing conflict, by demonstrating signs of failure to thrive through low weight gain, slow growth, and unresponsiveness.

The next stage of development is the toddler to pre-school stage, the period from almost two to about six years. Children in this stage are developing unique personalities. Parents are familiar with the "terrible twos" where children can be negative, contrary, and demanding. They grow through this contrariness and begin to seek approval and show pride in accomplishments. This achievement in developmental milestones is a direct result of the "terrible twos" where the child starts towards independence. Children begin to find a place in the world. Their primary attachment to parents expands. It is important not to misconstrue the negativity attached to the child in this period. Such behaviour is an example of normal development rather than any difficulty in parenting. Points (April 1994).

170 See I. Russ, "Bonding and Attachment" in Edwards, supra note 167, 22.

171 A basic understanding of attachment theory is useful. The attachment theory's leading proponents themselves have outlined a history of their approach: see M.D. Salter Ainsworth \& J. Bowlby, "An Ethological Approach to Personality Development" (1991) 46 Am. Psychologist 333. See also J. Bowlby, "Developmental Psychiatry Comes of Age" (1988) 145 Am. J. of Psychiatry 1. 
If parents separate during this period, the child's immediate needs are of primary importance. As children notice the conflict between their parents at this stage, fear and nervous upset begin to show. Children do not talk well about their stress or anxiety. Children need to understand and believe that they will be cared for by their parents. Actions are more important than words.

Throughout a child's development, expected milestones may be lost temporarily, or for longer periods, in response to physical or psychological stressors in the child's life. While distress is often demonstrated by regression, some regression is healthy. For example, a toddler who enters a strange environment, such as a hospital, may lose some of his newly acquired skills. Regression in this sense is a healthy psychological defence to this new event, especially when parents are absent. Parents and judges should not interpret it as abnormal. In other instances, such as where parental conflict continues, regression is a matter of concern.

Children in this pre-school period are increasingly verbal. They recognize stress in the world around them, and parents and judges correspondingly can recognize it in them. If difficulties with sleeping, eating, regression in motor activity, language acquisition and toilet training persist, and if there are pronounced difficulties in the child's social relationships, we should be alert to the causes or forces at play. ${ }^{173}$ If the child begins to show intense, emotional lability, the child may well be reacting to separation and divorce.

Children of separation and divorce also demonstrate great sadness because of the stress created by separation in this period. They withdraw and become listless. They become less interested in activities normally perceived as pleasurable. Such children may feel responsible for their parents' separation and in fantasies and dreams, they may personally take on responsibility for their parents' separation. ${ }^{174}$

Common stressors for children in this stage are lack of predictable daily routines, hostility between the parents, and emotional instability in the primary caregiver. ${ }^{175}$ When it becomes evident that divorce is imminent, when physical separation of parents is inevitable, changes should be as few as possible. If at all possible, mother and father should introduce the children to changes before they occur and then give the children time to adjust. Parents can help their children cope through frequent verbal and physical assurances of love and protection, repeated assurances that the absent parent will return, and discussion with the child in age-appropriate language about what is happening. Parents should help the child talk about the fears, sadness, anger, and frightening experiences that often arise after separation for children in this age frame.

The period of middle childhood adds new developmental challenges for parents. As the child learns and becomes socially interactive with peers, the child's developmental quest accelerates. The child moves towards becoming an autonomous person. The child 
can now reason at a different level and grows physically. Cognitive thinking at the commencement of this period is called pre-operational; for example, "the sun rises in the morning so I can go to school; it gets dark at night so I can sleep." The child is egocentric in the sense that the physical world carries on for the moment-to-moment needs of the child. About age eight, the child begins concrete thinking and reasons in terms of cause and effect. The child can now read better, do mathematics, and write in a logical way. Language has developed significantly, so the child can now maintain attention to tasks and learn effectively.

Such a child is now learning social interaction by acquiring rules; rules in the classroom, in the playground, in clubs, and in the home. Children appreciate understanding the boundaries of learning and playing. An active social network assists the child in accomplishing these tasks. Through rules children learn important skills of socialization: how to co-operate, how to compromise, how to win, and how to accept loss. Children are now developing a sense of right and wrong. It follows that if the child demonstrates delays or distortions in accruing these necessary skills, there is a problem that needs attention.

A common fantasy for children in this age group is that mother and father will reunite and the family will be intact. The loss of family clearly has an impact upon their development at home, in their neighbourhood, and at school. Family is of central importance to children at this developmental stage. Children like to participate in family activities. This is a difficult stage of separation and divorce for children. Children begin to interact with mother and father if there is separation in the hopes that their fantasy can be achieved. Children fear abandonment because, up to now, a healthy bond and attachment has likely been experienced. One of the most effective ways of dealing with such children is to remind them that parents are not married to the children, and therefore the parents cannot divorce the children. This will assist the child in coping with something the child cannot control. The best general advice is to have parents maintain contact so a sense of family exists, to whatever extent possible in the circumstances.

It is essential that the parents set up structures and routines so the child knows and understands his or her relationship with each parent. Parents must avoid power struggles lest a child take on a "parentified" role and buy into the dispute for the child's misinterpreted purposes. It is important that both mother and father tell the child that the child can love each parent, even though there is a separation.

It is especially important to look to the reactions of children in this stage to see whether or not there was any indication of problems prior to the family tension and breakdown. While the parents may be unable to assess new difficulties, the school often can. The child may become overly quiet during class and in play activities. The child may indicate sombre themes through drawings. Such actions may be reactions to the divorce, demonstrating the child's sense of loss, possible guilt, feelings of rejection, and loneliness. As the child moves through middle childhood, anger is a frequent sign of stress. Conflicts begin to develop between the child and the custodial parent over chores, participation in extra-curricular activities, and social relationships. Everything 
seems to become a point of contention, and the parent cannot cope. Parents often do not connect their child's behaviour to the separation. Unless arrested, the child's behaviour can become a self-fulfilling prophesy - the child grows up to be an angry, unpleasant and uncooperative person.

All children display their own emotional and behavioural reactions to the separation and divorce process relative to their existing level of development. Parents must comprehend that their decisions affect their children. Certain tasks must be successfully dealt with by the children and the parents together so they can cope - acknowledging the divorce and relinquishing longings for the restoration of the pre-divorce family, regaining a sense of direction and freedom to pursue customary activities, dealing with the feelings of loss and rejection, forgiving the parents, and resolving fears that they will be unable to achieve a successful relationship. ${ }^{176}$

Armed with knowledge of these features, which rise again and again in family separations and families in conflict, the judge has an important role in helping parties settle their problems. As the judge acts as a catalyst in the problem-solving process, the judge needs to understand the factors beyond the legal world which impact on this process.

\section{The Mediation Process in the Model}

Haynes' generic model of the mediation process is adopted here: (1) recognizing the problem; (2) choosing the arena; (3) selecting the mediator; (4) fact finding; (5) defining the problem; (6) developing options; (7) redefining positions; (8) bargaining; and (9) drafting the agreement. ${ }^{177}$ By adopting this model, a judge has a ready-made guide to lead the parties through the process.

When parties come before the Court on the first docket appearance, their problem is not necessarily clear or obvious. Under the current system, affidavits do not assist the parties or the Court in identifying the problem. It is essential then for the Court to help parties define the problem. The first step is better affidavits, prepared by the Court, completed by both parents, so their story is before the Court.

Under existing Court procedures, litigants cannot choose their mediator. However, the Court provides experienced judges interested in this process as mediators, who have appropriate skills. With the proposed model, the Court allots one judge to one family. The judge who appears in docket court the day this case comes forward must be the judge who offers this process to the parties.

Fact finding is an essential problem in all court systems. Once the assigned judge receives the required affidavits, the judge moves on to gather further material on the nature of the dispute, the background of the parties, the needs of the children, and the 
histories of all parties relevant to the dispute. The judge requires as much information as possible in the shortest time possible. The judge shares all information with the litigants. When necessary, information can be verified. The process assists litigants by clarifying information, defining bargaining issues, and educating each party to the other's point of view.

One of the benefits of mediation is that it is a controlled, pedagogical process. The mediator hears from each party, one at a time. In consequence, the other party is forced to listen to another point of view, perhaps for the first time. Through the age-old adage of walking a mile in someone else's shoes, a person gains understanding he or she did not have because of the conflict. Exchanging information is quite different from exchanging threats. The judge controls the process and outlaws inappropriate behaviours. The judge does not tolerate intimidation tactics or threats of violence. If these continue, the judge has the right to close down the mediation and end the process, just as the parties have this right.

The parties must understand that the judge is asking for information that the judge can obtain through subpoena power under the law. The parties' protection is litigation privilege. Litigation privilege is a power-balancing technique and must be adhered to when the Court adopts a child-centred perspective. The essence of co-operative bargaining is an exchange of all relevant necessary information. This is no time for a parent to withhold relevant information. The party who withholds information indicates mistrust and lack of commitment which could, if continued, end the mediation.

With information exchanged, the judge is now able to help the parties define the real problems they must resolve. Haynes points out that all participants in mediation "attempt to define problems in a way that (a) minimizes their responsibility for the problem, and (b) moves the onus for change to the other participants." ${ }^{178}$ Problem definition is a mutual function, and one parent cannot capture the agenda by unilateral definition. The judge must become skilled in perceiving and identifying such imbalances.

The judge assists the parties in developing options. Again, mediation stresses the mutuality of option development. As one-sided problem definitions have been cast aside, both parties must find ways to resolve their dispute. The judge must add the child's dimension to this discussion. The judge's experience plays a significant role here because of judicial independence and objectivity. Judges have no direct emotional investment in this private dispute. Creativity is the key. Many parties think in terms of win-loss. Now that the Supreme Court has declared that on separation and divorce a guardian does not lose all his or her rights when the other guardian obtains a sole custody order, ${ }^{179}$ this new understanding avoids some of the old mythology. The language of joint custody is no longer a required artifice to buy parents into settlements. Many parents have difficulties in custody cases, not because of what they want, but because of what they fear they will lose. Most parents want to remain connected to 
their children. Children need to be connected to them. Parenting is hard work. Sharing parenting functions through visitation is useful to the primary caregiver. Many parents have not thought new options through because of turmoil arising from the stress of separation. This stage of mediation is essentially a brainstorming one. It is a time to draw up lists of proposed ways to resolve the dispute, regardless of how unimportant or unusual a point may be. It is not a time to debunk the other person's ideas. Once potential solutions are discovered, the judge invites the parties to see which ones are possible and what common ground exists. Once the judge eliminates unacceptable suggestions, remaining ideas can be discussed, consequences considered, and means to achieve them debated.

It is now time to redefine the tentative positions earlier reached. The judge attempts to move the parties from position bargaining to interest bargaining. ${ }^{180}$ The judge then connects the interests of the adult parties to the needs of the child, viewed from a child development perspective. The judge suggests options which give the parties and the child the greatest benefit at the least cost, measured in terms of time, money, emotion, or any other relevant factor.

The parties are now ready to bargain. They have all the necessary information, they have defined the problem they must resolve, they have a sense of the options available to them, and they have organized these into goals. The judge knows how people bargain and continues the mediator's role by keeping participants on task through cooperative problem solving, not through zero sum bargaining.

One of the great inducements to settlement at this stage is Fisher and Ury's BATNA, the "best alternative to the negotiated agreement." ${ }^{\text {18I }}$ The parties understand there are constraints on their bargaining. First, every party to a negotiation understands there is an alternative, the trial, where another judge will be the decision-maker, not the parties. If this alternative is more acceptable than the negotiated settlement, parties have no inducement to settle. Second, the judge cautions the parties that if they intend to use the Court for either a consent order or a trial, the Court is not bound by their bargain as the Court speaks for the child and makes an independent assessment. Parental interests must obviously be considered since children are not raised in a vacuum; however, the child has first call, ${ }^{182}$ and the Court must be more concerned about the child's interests than the parents' wishes or interests. This restraint is a simple choice: either the parents find mutual agreement through a negotiated settlement or they accept the constraints of the Court system. Haynes describes this choice as a WATNA, each party's "worst alternative to a negotiated agreement." ${ }^{183}$ The parents may fear a court more than what is happening in the mediation process. Under a case management model, if judicial mediation or the mini-trial does not achieve dispositional success, a

R. Fisher \& W. Ury, Getting to Yes: Negotiating Agreement Without Giving In (New York: Penguin Books, 1983).

181 lbid. at 104.

182 See for greater elucidation of the first call principle United Nations Convention On the Rights of the Child, supra note 1.

183 
judge shall be ready to hear and decide the case without delay. This, and the restraints of the trial process, make the flexibility of the negotiated settlement a powerful inducement to settlement.

The greatest difficulty for a judge acting as mediator is understanding that he or she is not deciding the case. Lawyers are able to grapple with this distinction when they take mediation training because they recognize they have been assisting clients in solving problems all their professional lives. This said, the judge has a great advantage in this role. First, by definition, a judge is not for or against a party; the judge is independent. Second, a judge understands the necessity of balancing between disputants. Third, a judge is master of his or her own house and controls the court process. It is not difficult for the judge to understand the need of a mediator to control process, yet leave control of ultimate decision-making to the participants. Fourth, a judge is not swayed easily by unilateral actions, words or deeds, and will not be taken in by the articulate style of one of the participants in the lawsuit. Fifth, a judge is used to obtaining information to make a decision. A judge has an understanding of the problems and some of the ways they can be resolved in the child's best interest. Sixth, a judge has the ability to assess the parties and hear what they are really saying; a judge is an effective listener. Seventh, a judge can keep everyone on task and not allow the process to take on a life of its own. Finally, a judge understands better than most the limitations on people in terms of time, money, and emotion. A judge is motivated to find wise solutions for the benefit of the child and if these can be reached before trial, a judge will be well satisfied.

Haynes has suggested several strategies to assist the mediator's task. ${ }^{184}$ The first strategy is "normalizing." Many parties feel their problem is abnormal because they cannot solve it themselves. For this reason they have brought the problem to a third party. The judge can convince parties that, from his or her experience, theirs is a usual difficulty to which solutions are available. If the situation is therefore normal, normal solutions are readily available. The judge can use case examples to make the point.

Haynes' second strategy is one of "mutualizing." Haynes notes that most parties to disputes deny personal responsibility for the problem and invariably want to pass it on to someone else. Positioning invariably involves attack on another. The mediator must help parties let go of their individual difficulties in favour of mutuality. Nothing could be clearer in custody cases. Parental guardians have a never-ending duty to the child. Parents will be involved together with their children over the long term.

Haynes' third strategy is "future focusing." This can be problematic. Granted, when deciding custody disputes, a judge looks for future-orientated solutions. However, a judge cannot ignore the past. The past reveals many things important to decisionmaking for parents or by the Court. It is important that the judge let people tell their version of the facts. A judge cannot solve the problems of the past. A judge cannot and should not decide who was right and who was wrong about past acts, nor can the judge change what is in the past. A balanced approach is the best tactic. As the decision 
concerning children is prospective in nature, the parties should not languish in complaints about the past; rather they should use information about the past to assist in future decisions. Often, in so doing, parties attempt to have the mediator take on the role of judge and seek validation of some perceived wrong. Haynes appropriately noted that the past is unchangeable. Talking about the past does not resolve it, though it can have therapeutic value. Talk must not be allowed to continue at length and usurp the real function of the mediation.

If mediation fails to resolve the dispute after reasonable effort, the judge can offer his or her services as an independent, objective voice. The judge now converts the mediation process into a mini-trial. The mini-trial allows the parties a further opportunity to involve themselves directly in the process by letting them state their cases and arguments. The parents must prepare a parenting plan in order to qualify for a mini-trial. ${ }^{185}$ A parenting plan requires mother and father to think through their responsibilities, their duties to their child, and future arrangements necessary to fulfil these responsibilities. If we accept the fundamental premise that parents are guardians with duties, parties can be judged on how they honour this responsibility.

The proposed judicial model purposely employs the mediation and mini-trial process to advise the parties about information that allows for meaningful discussion by parents on what is best for their child in their particular circumstances in a non-adversarial context.

\section{STAGE THREE: THE TRIAL}

For those cases where settlement is not possible, a trial brings closure on the custody issue. Trials proceed in the usual way. While in the past there existed a suggestion that family court trial hearings were informal with a "let it all in" approach to evidence, this can no longer continue. Trials must be proper trials in every sense of the word as informal alternate dispute mechanisms have been tried. The Court hears all relevant, admissible evidence and applies the law. At trial, there is no room for a judge's personal view or interest. As McLachlin J. noted in Young: "He or she must not do what he or she wants to do but what he or she ought to do." 186 The judge must apply the best interest of the child standard objectively. While expert evidence may be helpful in some cases, it is not necessary to establish the best interests of the child. This

The State of Washington in their 1987 Parenting Act has done several innovative things. First, they have abandoned the language of custody viewed from the traditional sense and now talk about parenting as opposed to custody and access. It has adopted a functional approach and the statute identifies four areas of parenting based on the needs of children that must be addressed in a parenting plan. These four areas are: 1) the child's residential arrangements; 2) the provision for financial support; 3) the allocation of decision-making authority and 4) a dispute resolution process. The parenting plan must indicate who is responsible for the day-to-day care as well as specifically allocate decision-making to one or both parents in the major areas of education, health care and the religious upbringing of the children. 
question is normally decided on the evidence of the parties and the testimony of the children, where appropriate. ${ }^{187}$

Family and Youth Court judges are accustomed to hearing children's evidence. Judges are sensitive to the needs of children in the courtroom setting and will make the necessary accommodations for them. In private family disputes, calling children as witnesses is rare. At trial, the hearsay evidence rule prevents mother or father from testifying as to their children's views and opinions. ${ }^{188}$ Perhaps children are rarely called because of their youthfulness; they are thus prevented from giving significant evidence on the critical issue of their future. Perhaps children in the toddler to middle school years do not possess sufficient comprehension of their own needs to give meaningful evidence of their wishes. ${ }^{189}$ Perhaps they are unduly influenced by the emotional factors cited above. Certainly older children's views demand respect, provided those views are reasonably well thought out.

The fundamental task of the trial judge is to find fact. There should be little difficulty with this in custody cases. Not unexpectedly, the critical issue will be the application of the best interests of the child standard, as defined and interpreted in the law, to the facts. How have judges fared in this task? A 1971 study of Ontario Supreme Court judges found a judicial distaste for custody cases. ${ }^{190}$ The emotional component of a custody case is a central feature of such views. Judges in adversarial custody cases rarely gained a true, unbiased picture in custody trials. Trials are parent-driven, not child-focused. Under adversarial proceedings, the vast majority of cases never reach trial because judges made serious attempts at settlement. Of the cases which went to trial in the late 1960 s and early 1970 s, most offered only one realistic solution. Since one of the parties was not being realistic, or was emotionally overwrought, or driven by improper motives, the trial resulted, not from concerns about what was best for the child, but from the personal positions of a parent.

Bradbrook recognizes a wide spectrum of factors, attaching various weights to each. One factor of note was the wrongful parental act, such as the unilateral taking of a child by a parent. Such acts did not gain unanimous disapproval by judges. The circumstances of the taking were as important as the act of kidnapping. Only two judges Bradbrook interviewed saw this issue in terms of trauma to the child. Conversely, judges saw a parent who voluntarily gave up care and control of a child as disinterested in the child; this factor weighed heavily against such parent's future custody claim. The inference drawn was that the parent did not care much for the child. Bradbrook also notes the primary caregiver presumption in favour of the wife. Judges in the study rationalized that father could not give the child full-time care and devotion

Ibid. at 168, Cory and lacobucci JJ.

The rigours of the hearsay rule can be avoided through a principled approach by applying the necessity and reliability exception of the hearsay rule. See $R$. v. Khan, [1990] 2 S.C.R. 531; $R$. v. Smith, [1992] 2 S.C.R. 915; R. v. K.G.B., [1993] 1 S.C.R. 740.

See Jandrisch v. Jandrisch (1980), 16 R.F.L. (2d) 239 at 250 (Man. C.A.).

A. Bradbrook, "An Empirical Study of the Attitudes of the Judges of the Supreme Court of Ontario Regarding the Workings of the Present Child Custody Adjudication Laws" (1971) 49 Can. Bar Rev. 557. 
because of the demands of work. An intuitive preference for mother existed. De facto possession of the child was a factor of some importance for Bradbrook as well who suggests that the real trial in custody cases was the interim custody hearing, not the trial itself. The status quo argument was a strong factor, rarely upset. ${ }^{191}$ Bradbrook uses a scenario approach to interview judges and found a disparity of opinions. Like cases were not treated alike by all judges. Bradbrook discovered that the best interests of the child standard meant one thing for one judge and another for a different judge.

Pearson and Ring, in a study centred in the Denver, Colorado, area between 1973 and 1978, examine judicial decision-making in contested custody cases, viewed from the shift in the legal test from a parental rights perspective to the more elusive best interest of the child standard. ${ }^{192}$

Pearson and Ring discover a distinction in how judges of three counties decided cases. Denver judges did not seem to conform to the traditional criteria of child custody determination. They were more youthful and inexperienced with domestic relations than their counterparts. Furthermore, they were put into the Domestic Relations Court as their first sitting. Potentially, this could suggest that a new judge was more in step with the views of the community. Pearson and Ring find Denver judges younger and more eclectic by background than their counterparts in the other counties.

Judicial interviews demonstrated a continuing attachment of judges to the tender years presumption. However, younger judges expressed less reliance on "tender years" as they found motives of parents and relationships between parent and child more important to the decision. Age differences showed up on same sex decisions as well. Older judges found placing children with the same sex parent an important criterion, while younger judges did not feel this to be as important. Moral issues were an issue for younger judges when they affected child rearing. Older judges were more ambivalent. Children's wishes as a criterion did not attract unanimity. Some felt this was unimportant, while others discussed custody decisions with children all the time.

With few exceptions, Pearson and Ring note that most judges disliked domestic relations cases and custody adjudication in particular, complaining of crowded dockets, pettiness of the parties, emotionalism and "the absence of true legal issues." 193 Custody cases were worrisome. One judge said that: "[c]ontested cases are absolutely hard cases. I am playing God ... you can do extreme damage. Usually before a decision I do not sleep. My stomach hurts. I would rather send someone to life in the penitentiary."194 A central reason for this judicial Zeitgeist was that judges were required to make difficult predictions about future behaviour that could be supported

Ibid. In Alberta, subsequent to Bradbrook's paper, the Alberta Court of Appeal dismissed this thinking in Roebuck v. Roebuck (1933), 34 R.F.L. (2d) 277 (Alta. C.A.). In sum, interim orders were just that, interim orders, and they had no persuasive weight on a per se basis. J. Pearson \& M.A.L. Ring, "Judicial Decision Making in Contested Custody Cases" (1982) $21 \mathrm{~J}$. Fam. Law 703. 
by facts. ${ }^{195}$ Yet judges remained virtually unanimous that wide judicial discretion should be retained, and these cases continue to be heard in a judicial forum. The uniqueness of child custody cases demands flexibility; otherwise, as one judge suggested, judges could use a computer. Judges were reluctant to delegate decisionmaking to another forum or to other professionals. Their view stands in stark contrast to their distaste for this judicial work. Some judges had reservations over their qualifications to handle domestic relations as well. The conclusion Pearson and Ring drew was clear: judges are human and reflect the dominant social values of their class and generation.

Atkinson examines 241 reported appellate cases nationwide in the United States for the year 1982. ${ }^{196} \mathrm{He}$ seeks out the predominant factors but noted an important caveat: "The only absolute in the law governing custody of children is that there are no absolutes." 197 The general standard used in appellate decisions was the best interests of the child, a sex-neutral term. In a majority of states no preference was given to mother. The burden of proof in custody cases was placed equally on both parents. Atkinson finds particular factors used in these court decisions and notes the relative frequency with which these factors were applied. ${ }^{198}$ His analysis shows fathers were making substantial progress in obtaining equal treatment with mothers in custody cases. Atkinson suggests this occurred, in part, because fathers were more involved as parents than they had been previously. Hence, judges viewed them as equals with mother. This notwithstanding, the tender years doctrine, whether in the form of statutory presumption or judicial imperative, continued to exist, especially as a tie-breaker. A child's age or sex may be a back door approach to this doctrine, notwithstanding constitutional breach of due process and equal protection clauses of the American Constitution. Atkinson suggests a child may be denied due process by having the custody determination decided by sexual presumptions rather than by the facts of the case. Atkinson forcefully argues for equal consideration of both mother and father as a starting point in determining custody.

Atkinson notes numerous factors found in the appellate opinions he studied.

Primary Caretaker: Atkinson finds the primary caretaker to be an important factor especially with children ten and under. Courts were able to identify who was the primary caretaker as a finding of fact. This implied there had been a closer relationship with the child and this parent than the other, that this parent had more experience in meeting the child's needs and therefore, inferentially, this primary relationship should continue. Assuming that a child was developing on par, why make a change when the primary caretaker parent in the past had shown such a commitment? Atkinson cites Garska v. McCoy to define "primary caretaker."199 Parenthetically, it is important to

J. Atkinson, "Criteria for Deciding Child Custody in the Trial and Appellant Courts" (1984) 18 Fam. L.Q. 1.

197 Ibid. at 4 citing Friederwitzer v. Friederwitzer, 55 N.Y. 2d 89, 432 N.E.2d 765 (1982).

193 Ibid. at 9 (Table A).

$199 \quad 278$ S.E.2d 357 (W. Va. 1981). 
note that Atkinson uses the word caretaker not caregiver. The term caretaker comes from Garska v. McCoy. Use of the term "primary caretaker" reflects a movement away from maternal preference to a primary caretaker presumption.

Atkinson suggests that replacing "one wooden rule"200 with another does not advance the best interests of a child. The primary caretaker factor should not necessarily supersede other factors that come into play when judges decide custody. Again, he asserts that it may very well be unconstitutional to make this factor controlling since it denies due process to the child: "The U.S. Supreme Court has held it is a denial of due process to make a "permanent and irrebuttable presumption ... when that presumption is not necessarily or universally true in fact, and when the state has a reasonable alternative means of making the crucial determination." ${ }^{201}$

Time Available to Spend With Child: The primary caretaker factor is retrospective in operation. "Time available to spend with the child" is prospective. The flex-time parent's job may suggest an advantage for the child. Time available presupposes a commitment to spend this time with the child. ${ }^{202}$

Time Spent With a Parent Pending Trial: The fact that the child had been in the custody of one parent during pre-divorce separation or pending appeal was a factor in favour of the parent who had this physical custody. This was especially important where the physical custody was consensual. The status quo argument reflected continuity concerns. The longer the parent had the child, the greater the weight of this factor. However, if a court made an interim order primarily to stop the conflict surrounding the child pending trial, time spent with the parent pending trial would not be a controlling factor. ${ }^{203}$

Integration Into Family: One basis for modifying a custody award was integration of the child into the family of the petitioning parent with consent of the custodial parent. By reason of such consents these cases did not often find their way into court. If the consensual arrangement was intended to be only temporary for a specific purpose, no difficulty arose; such an arrangement may be the mark of good parenting and should not prejudice such a parent. Valid temporary custody changes for health problems, marital problems, schooling or work were all viable, reasonable explanations for such arrangements. When they existed, courts did not allow a non-custodial parent to take advantage. When these arrangements continued over time, continuity of care and stability for the child resulted. The degree of integration and the impact of change for the child demonstrated the degree to which judges based custody decisions on "integration into the family." 204

\footnotetext{
$200 \quad$ Atkinson, supra note 196 at 18.

201 Ibid. at 18 citing Vlandis v. Kline, 412 U.S. 441 (1973).

$202 \quad$ Ibid. at 19.

$203 \quad$ Ibid. at 20.

204 Ibid. at 20-21.
} 
Stability of Environment: This is a catch-all factor which overlaps many others. Courts looked at what was working. If the child was thriving, well adjusted, and well cared for where he or she currently lived, then there was no reason for change. Children are by nature very conservative. Any restructuring of a child's residence can be distressing or problematic. "Stability of environment" can be easily established by objective evidence. Questions to establish this factor included: how is the child's health? How does the child relate to peers? How does the child behave in the neighbourhood? At school? In the large family context? If there are no significant problems, why make changes? ${ }^{205}$

Religious Training: While this can be a factor, it rarely was a controlling one. The right to individual religious choice is recognized. This was not the issue. The issue was whether a parent's choice of religion and the manner in which it was preached or practised had an adverse impact on the child. Interestingly enough, the absence of religious training and its potential for adverse effects was not noted in these appellate decisions. $^{206}$

Abuse and Neglect: These are obvious factors. While society may not know all the factors which constitute a "good-enough" parent, and may fail to agree on what "good enough" means, society agrees on what a child needs as a minimal standard. Child welfare laws permitting state intervention when parental care falls below a minimally accepted standard are predicated on this concept. Any significant abuse or neglect by a parent of a child will be a determinative factor. Abuse can be physical, verbal or emotional. Abuse does not have to be directed against the child. Violence by a spouse against a spouse is not acceptable and would be sufficient to change custody. ${ }^{207}$ Neglect is a more elastic term and includes lack of supervision, poor physical care of the child, lack of basic attention to the child's health needs, inadequate provision of food, clothing or shelter, and supervisional neglect. Consonant with the principle of duty, a parent who does not pay child support could be neglecting his or her child. ${ }^{208}$

Alcohol and Drug Problems: This is a self-evident factor. A child should not be exposed to abuse in the area of drugs or alcohol, either by the parent, the parent's consort, or others in the child's environment. ${ }^{209}$

Mental Instability: If a parent had a significant mental health problem which prevented him or her from navigating satisfactorily in today's complex world, it followed that such person could not parent effectively. This said, past problems appropriately dealt with (where the parent is rehabilitated or recovered) should not be used as grounds for denying custody. ${ }^{210}$

L.D. Eron et al., "Reason to Hope, A Psychosocial Perspective on Violence and Youth" (1994) American Psychological Association. Atkinson, supra note 196 at 23-24. Ibid. at 24.

Ibid. at 24-25.
} 
Perjury and Other False Statements: Parental demeanour and credibility influences judges. When a parent deliberately manufactured evidence or factually misrepresented evidence to bolster his or her case, a judge can employ this criterion to decide custody as this parent advanced his or her own interests over that of the child's. In this sense, arguably, the making of a false allegation of child abuse can be abuse itself. ${ }^{211}$

Interference With Visitation: At the time of Atkinson's 1982 study, society had accepted the fact that children of divorce needed both parents. Children are affected by divorce. To avoid the impact of disruption, they need all the security parents can provide. It was believed that ongoing parental contact alleviated trauma. This factor, akin to the so-called friendly parent rule, is an obvious factor based on a child-centred perspective. ${ }^{212}$

Frequent Changes of Residence: A parent who moved frequently, involving school changes, created a risk factor for the child. Judges allied changes in residence to stability and continuity concerns. Yet movement of residence may not necessarily be determinative of stability. Atkinson notes stability is more a function of parental attitude than geography. ${ }^{213}$

Moving Away: The mobility question created a factor, especially in modification hearings. Atkinson noted a number of factors arose from the cases, some of which may conflict. $^{214}$

Non-Marital Sexual Relationship (Heterosexual): Atkinson finds a judicial tangle in this area of the law. There are some areas of agreement. A parent's discreet sexual relationship, unknown to a child, was not a factor, of itself. If, however, the parental relationship became so time consuming that it factored into the child's needs, then it became a decisive factor. If a parent was promiscuous and this was well known to the child, a court may question the appropriateness of this behaviour. ${ }^{215}$

Homosexuality: The courts were ambivalent on this factor. On balance, homosexuality per se was not a factor. How the homosexual relationship interfaced with and affected the child was the key. ${ }^{216}$

Relationships With Step-Parents or Step-Siblings: In a society of families, however the term is defined, the corollary of divorce is remarriage. It follows that the quality of the family relationship, which can involve step-parents and step-children, was important and could be a positive or negative factor. The timing of this new relationship may be important. If a parent recently remarried and the child was upset in the new family unit,

\footnotetext{
Ibid. at 25 .

Ibid. at $25-27$.

Ibid. at 27.

214

Ibid. at 27-28 citing Hale v. Hale, 429 N.E. (2d) 430 (Mass. App. Ct. 1981). Compare with Gordon, supra note 65.

$215 \quad$ Ibid. at 29-32.

216 Ibid. at 32-34; for a discussion of homosexuality and custody see R.A. Beargie, "Custody Determinations Involving the Homosexual Parent" (1988) 22 Fam. L.Q. 71.
} 
upset could be explained by the commencement of this new family relationship. Allowing time for adjustment was not unreasonable. If, however, the relationship was long standing and problems continued or erupted because of the new relationship, courts took a different view. ${ }^{217}$

Help From Grandparents And Other Relatives: This was a special kind of child care issue. The norm in society is that usually both parents must work. Day care and family care were now issues. If the family support network offered a positive relationship to the child, this buttressed a parent's claim for custody. If however, the extended family was in reality the sole primary caregiver, it was a different kind of factor. Kinship was and is a recognized social value. ${ }^{218}$

The Child's Preference: This was always a factor. The weight to be given this factor was the issue. This depended on the child's age, intelligence and maturity. If the child could express a good reason for a preference, courts should respect and follow it, absent other compelling reasons. If the child was nothing more than a mere proxy for a dominant parent, no weight should be given to the child's preference. There was no magic age for a child to be able to express his or her preference. ${ }^{219}$

Atkinson concludes his survey by noting the ever-increasing use of various factors in deciding custody cases. Mother and father were treated with greater equality. Judges paid primary attention to the factual merits of individual cases. He suggests that to forestall the constant fear of judicial bias, judges articulate more findings of fact. This required judges to review all pertinent factors.

This survey now turns to Lowery who, in 1981, examined the process judges in Kentucky used to decide custody cases in accord with the best interests of the child standard. ${ }^{220}$ Lowery employs a self-report technique where judges were asked to analyze the relative importance they assigned to various factors in deciding custody disputes. Lowery hypothesizes that, given the multiple factors to be considered, judges relied more heavily on some than on others, thus reflecting a manageable number of dimensions to be used in deciding custody cases. To test this hypothesis, she creates a twenty item questionnaire through pre-test investigation. This list, ranked by order and mean rating, is:

1. Mental stability of each parent,

2. Each parent's sense of responsibility to the child,

3. Biological relationship to the child (when one parent is a step-parent),

4. Each parent's moral character,

5. Each parent's ability to provide stable community involvement,

6. Each parent's affection for the child,

218 Ibid. at 35 .

$219 \quad$ Ibid. at 33-36.

220 C.R. Lowery, "Child Custody Decisions in Divorce Proceedings: A Survey of Judges" (1981) 12 Professional Psychology 492. 
7. Keeping the child with brothers and sisters,

8. Each parent's ability to provide access to schools,

9. Keeping a young child with the mother,

10. Physical health of each parent,

11. The wishes of the parents,

12. Professional advice,

13. Biological relationship to the child (when one parent is an adopted parent),

14. Each parent's financial sufficiency,

15. The child's wishes,

16. Length of time each parent has had custody,

17. Each parent's ability to provide contact with the child's other relatives,

18. Each parent's ability to provide access to other children of about the same age,

19. Each parent's ability or intention to provide a two parent home,

20. Placing a child with a parent of the same sex. ${ }^{221}$

Lowery, in a second study completed in 1984, 222 continues her work in analyzing how court decisions were made in custody cases. In this second study, she combined a survey of judges with one of mental health professionals. There were more areas of agreement between these two groups than disagreements though group differences did emerge. Mental health professionals tended to give significantly greater emphasis to the quality of the relationships between parent and child while the judiciary emphasized the legal-biological status of the parent-child relationship and traditional family values and structures. Both had the same objective - to find better ways to improve the adjudication of custody disputes. Yet her examination of the behavioural science literature regarding standards and procedures for resolving such disputes yielded spartan results.

One theme that emerged in Lowery's second study was that divorce is a process which alters family structures rather than disintegrates them. Lowery therefore asserts custody cases should be evaluated primarily on the basis of interpersonal relationships among the parties, i.e., the parent-child-parent relationship. This entails looking not only at the dynamics of the immediate family triad but also at the child's secondary social networks - the child's close connections to friends, the community, the school and close relatives. Lowery says courts should maintain these in the child's interests so far as possible. The custody process must resolve the issues existing between the parents to encourage an amiable post-divorce relationship between them which can be maintained by an accompanying schedule of flexible visitation to the non-primary caregiver parent. This allows the child to cope best with the stressors brought on by separation and divorce.

222 C.R. Lowery, "The Wisdom of Solomon: Criteria for Child Custody from the Legal and Clinical Points of View" (1984) 8 Law and Human Behaviour 371. 
Lowery compares the weighting of factors by judges and mental health professionals and again uses a questionnaire model based, in part, on her earlier study. ${ }^{223}$ Lowery finds the two groups do not differ in their assessment of thirteen of nineteen items. Both groups identified an assessment of parents as stable, mature, responsible adults to be the dominant factors in their conceptual approach to custody disputes. Both groups paid substantial attention to the child's secondary social networks, i.e., peers, relatives and school. Mental health professionals placed significantly greater emphasis than judges on the child's wishes and the quality of the emotional relationship between parent and child. Courts tended to rely on traditional values which could be easily identified by objective evidence. Fact-based material was more accessible to the court. If mental health professionals did not come to court to advance their choices based on empirical data, a judge did not speculate. Judges tended to be practical in focus and employed that which they measured. If a judge found adequacy, it followed, through inferential reasoning, that a parent was adequate. Put another way, if a judge found that physical care was adequate and a child was developing on par, the judge inferred that such parent would be adequate in the future.

In 1989, Reidy, Silver, and Carlson surveyed California judges on child custody decisions. ${ }^{24}$ Building on previous studies by Lowery, they were interested in knowing the impact on judges of data received from mental health professionals. They discovered several distinct trends. Judges gave greater weight to evidence from nonpartisan sources, then parents, then older children than to evidence connected to a parent or to a younger child. Court psychologists were preferred over partisan psychologists retained by a party. Most judges recognized joint physical and legal custody awards had not worked well in contested cases despite a statutory preference for joint custody in California. Judges and mental health professionals strongly agreed on the rank ordering of criteria for deciding between joint or single parent custody, i.e., "age of the child, willingness to enter joint custody, quality of the parent-child relationship, amount of anger bitterness between the parents and psychological stability of the parents." ${ }^{.225}$ The least relevant factors for deciding joint compared to single parent custody included "gender, wishes of a young child, age of the parents, economic/physical similarities and differences, marital status of parents, and parental economic stability. ${ }^{1226}$

In Canada, in March, 1993, the Department of Justice published Custody and Access: Public Discussion Paper. ${ }^{227}$ It compiled a summary of the different factors statutorily mentioned in provincial legislation that courts should consider in deciding custody. This synthesis of Canadian social policy is a useful summary of what is seen in the case law over time. This list is not weighted nor set out in any priority or degree of importance.

Ibid. at 375 .

224 T. Reidy, R.M. Silver \& A. Carlson, "Child Custody Decisions: A Survey of Judges" (1989) 23 Fam. L.Q. 75. 
- Conduct of the parents

- The wishes of the father and the mother

- The health and emotional well-being of the child including any special needs for care and treatment

- Where appropriate, the views of the child

- The love, affection, and similar ties that exist between the child and other persons

- Education and training for the child

- The capacity of each person to whom guardianship, custody, or access rights and duties may be granted to exercise these rights and duties adequately

- The effect upon the child of any disruption of the child's sense of continuity

- The love, affection, and ties that exist between the child and each person to whom the child's custody is entrusted, each person to whom access of the child is granted, and where appropriate, each sibling of the child

- The child's cultural and religious heritage

- The length of time the child has lived in a stable home environment

- The ability and willingness of each person applying for custody of the child to provide the child with guidance and education

- The necessities of life and the special needs of the child

- The ability of each parent seeking custody or access to act as a parent

- $\quad$ Plans proposed for the care and upbringing of the child

- The permanence and stability of the family unit with which it is proposed that the child will live

- The relationship by blood or through an adoption order between the child and each person who is a party to the application

- The personality, character and emotional needs of the child

- The capacity of the person who is seeking custody to act as legal custodian of the child

- The home environment proposed to be provided for the child

- The plans that the person who is seeking custody has for the future of the child

- The effect that awarding custody or care of the child to one party would have on the ability of the other party to have reasonable access to the child.

Combining these studies with the analyses in Part One, common understandings of pertinent factors develop over time. This occurs in the legal system through a case-bycase analysis. Thus, the legislature has wisely chosen to leave to the courts the task of deciding the relevant criteria for the best interest of the child standard and to decide the weight to be given such criteria in a particular case. At trial, the parties have full opportunity to present their case and emphasize which factors are relevant. Judges have the opportunity to make findings of fact and conclusions of law based on these community understandings about best interests outlined here. Articulated reasons for judgment are the expected norm. The litigants must understand the decision of the judge and the route the judge took to reach the decision. In such a case, the elements of subjective and objective justice are joined. 


\section{E. CONCLUSION}

The Provincial Court of Alberta is mandated to bring family law to every person's door and to make it work effectively. The Court's strength must be measured by its success in fulfilling this mandate. The current ad hoc nature of the methods employed to decide family disputes in the Court can be improved. The Court has the ability to control its own process and therein lies the key to meaningful and practical reform. Without legislative intervention, the Court can implement a uniform process with the ultimate goal of child-centred decisions made with maximum parental involvement.

It is proposed that a three stage process, uniformly followed, will increase the comfort of the public with the legitimacy of the process and result in decisions that are focused on the most important person in the case, the child, through the use of courtsanctioned (as opposed to individual judge-created) criteria for the best interest of the child standard. These criteria represent commonly accepted community understandings about this standard.

First, the Court must take control over the form of the court application. In this way the Court ensures it receives consistent, relevant information presented to it in a useful way, by an affidavit. The affidavit emphasizes the shift in focus from parental rights to the needs of the child.

Second, the Court must adopt a mediation role and mini-trial procedure to assist the parties in exploring their issues with the goal of privately resolving the dispute for the benefit of the child. Participation in this process of judicial dispute resolution will be a condition precedent to obtaining a trial date.

These first two stages are controlled by the judge yet require substantial parental involvement so as to provide the parties with a practical understanding about the best interest of the child standard, yet allow for individualized treatment of their dispute.

Third, and only if the mediation, mini-trial process is unsuccessful, the Court will provide a traditional, adversarial trial process for resolution of these issues through a court-imposed decision.

This new, non-legislated judicial dispute model should provide earlier settlements of custody issues that are more satisfactory to the parties. Hence, all children benefit. 